\title{
Radioimmunoassay of ACTH in Plasma
}

\author{
Solomon A. Berson and Rosalyn S. Yalow \\ From the Radioisotope Service, Veterans Administration Hospital, \\ Bronx, New York 10468 and the Department of Medicine, Mt. Sinai School of \\ Medicine, New York 10029
}

A в S T R A C т Techniques are described in detail for a radioimmunoassay of plasma adrenocorticotropin $(\mathrm{ACTH})$ that is capable of detecting hormone in unextracted normal human plasma at $1: 5$ dilution under the conditions described. The sensitivity of the assay is at the level of $1 \mu \mu \mathrm{g} / \mathrm{ml}$ (equivalent to $0.014 \mathrm{mU} / 100 \mathrm{ml}$ ).

In normal subjects ACTH concentrations averaged $22 \mu \mu \mathrm{g} / \mathrm{ml}$ (equivalent to $0.308 \mathrm{mU} / 100$ $\mathrm{ml}$ ) plasma at 8-10 a.m. In a smaller group the concentrations averaged $9.6 \mu \mu \mathrm{g} / \mathrm{ml}$ (equivalent to $0.134 \mathrm{mU} / 100 \mathrm{ml}$ ) at $10-11 \mathrm{p} . \mathrm{m}$. Although a circadian rhythm in normal subjects was not always well marked throughout the daytime hours, plasma ACTH usually fell to its lowest value in the late evening. In hospital patients who were not acutely ill, concentrations were infrequently above $100 \mu \mu \mathrm{g} / \mathrm{ml}$ in the morning and usually fell to significantly lower levels in the late evening. Severely ill hospital patients occasionally exhibited a.m. concentrations above $200 \mu \mu \mathrm{g} / \mathrm{ml}$.

In a group of subjects showing frequent spiking of plasma 17-OHCS concentrations throughout the day parallel spiking of plasma ACTH as well was generally observed.

Metyrapone produced marked increases in plasma ACTH within $24 \mathrm{hr}$ in all cases and generally within 3-6 hr except when started late in the day. Dexamethasone brought about a persistent reduction in plasma ACTH in a patient under continued treatment with metyrapone.

Hypoglycemia, electroshock, surgery under general anesthesia, histalog and vasopressin administration were usually followed by significant increases in plasma ACTH concentration. Prior

Received for publication 1 April 1968 and in revised form 26 August 1968. administration of dexamethasone blocked the response to hypoglycemia.

Marked elevations in plasma ACTH were observed in patients with adrenal insufficiency off steroid therapy, in Cushing's disease after adrenalectomy even in the presence of persistent hypercortisolemia, and in some untreated patients with Cushing's disease.

Umbilical cord blood contained higher plasma ACTH concentrations than maternal blood at delivery in seven of eight cases.

After suppression of ACTH secretion by dexamethasone or cortisol, ACTH disappeared from plasma with half-times ranging from $22 \mathrm{~min}$ to $30 \mathrm{~min}$ in three cases studied.

\section{INTRODUCTION}

The method of radioimmunoassay has been employed for the measurement of several peptide hormones in plasma. Adrenocorticotropin (ACTH) poses an unusually difficult problem because of its low concentration in the plasma of normal subjects. In a previous study (1) this difficulty was partly circumvented by extracting and concentrating ACTH from plasma samples containing too low a concentration for direct assay. In this paper we describe methods with sensitivity sufficient to permit the quantitative determination of endogenous ACTH in unextracted plasma of normal human subjects.

Principles of radioimmunoassay with particular reference to problems of sensitivity

The essential principle of radioimmunoassay involves the binding of an isotopically labeled peptide or protein to its specific antibody (2) and the 


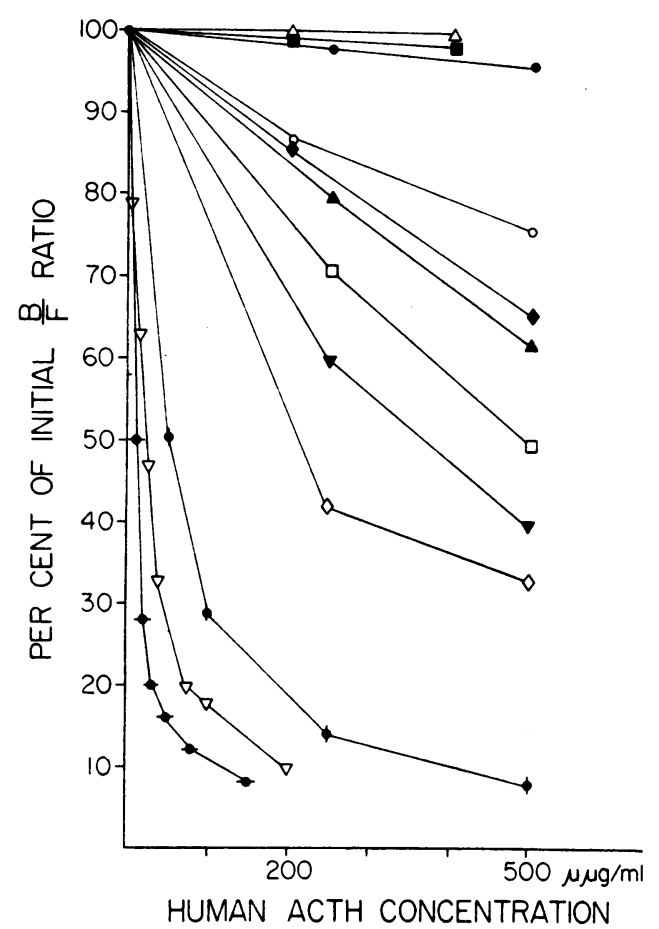

FIgURe 1 Guinea pig anti-porcine ACTH sera were diluted sufficiently to yield a $B / F$ ratio of $0.6-1.2$ with ${ }^{131} \mathrm{I}$ or ${ }^{125} \mathrm{I}$-labeled human ACTH in the absence of unlabeled hormone. The percentage change in $B / F$ ratio is plotted as a function of the concentration of unlabeled hormone.

competitive inhibition of such binding by unlabeled hormone in standard solutions and in plasma or other body fluids $(3,4)$. A "standard curve" may be constructed by plotting the ratio of bound (B) to free $(\mathrm{F})$ labeled hormone, $(\mathrm{B} / \mathrm{F})$, as a function of the total concentration of unlabeled hormone in known standard solutions. The concentration of hormone in an unknown sample is then determined from the $\mathrm{B} / \mathrm{F}$ ratio observed in the sample by reference to the standard curve. It is a matter of experience that antisera obtained from animals of the same species immunized on the same schedule show considerable variability not only in the quantity of antibody but also, and more importantly for immunoassay, in the slope of the standard curve (Fig. 1). The antiserum that yields the sharpest initial slope provides the greatest sensitivity for detection of low hormone concentrations. The antiserum used in th present work was selected from among approximately 230 antisera taken from about 50 guinea pigs immunized with porcine ACTH.

Since the slope of the standard curve is greatest at the vertical axis and becomes progressively more shallow with increase in hormone concentration, the initial slope approaches a maximum as the concentration of labeled hormone ("tracer") tends to zero. Ideally, the concentration of tracer employed should be reduced to less than the lowest concentration to be measured, but its practical lower limit will be determined by the statistical accuracy of counting and limitations in the counting time available. For a given concentration of tracer (weight of hormone per unit volume of incubation mixture) the counting rate will be proportional to $(a)$ the efficiency of the counter, $(b)$ the volume of mixture counted, and $(c)$ the specific activity of the tracer.

\section{METHODS}

Production of ACTH antibodies. Guinea pigs are immunized at irregular intervals by subcutaneous injection into the medial aspect of the thigh with porcine ACTH (Duracton, Nordic Biochemicals, Montreal, Canada, 40 $\mathrm{U} \mathrm{ACTH} / \mathrm{ml}$ in carboxymethylcellulose) emulsified in complete Freund's adjuvant. Approximately $75 \mathrm{mg}$ of metyrapone is included in the emulsification mixture in the hopes of preventing stimulation of cortisol secretion, which could theoretically inhibit antibody formation. ACTH antibodies are detectable in almost all guinea pigs after two to three injections of $25 \mathrm{U}$ each administered at intervals of approximately 2-4 wk. 8-10 days after imunization, blood is taken by cardiac puncture into heparinized syringes. The separated plasma is stored at $-17^{\circ} \mathrm{C}$ but stock dilutions of guinea pig antiserum (1:500 or $1: 1000$ in normal saline solution containing merthiolate 1:5000 and control guinea pig plasma, 1:50 or $1: 100$ ) can be maintained in the refrigerator many months without significant loss of antibody.

Specific activity requirements for $A C T H{ }^{-131} I$ and $A C T H^{125} I$. Porcine ACTH and human ACTH are molecules of approximately 4500 molecular weight and contain two tyrosyl residues. For carrier-free ${ }^{121} \mathrm{I}$ and ${ }^{125} \mathrm{I}$, the maximal specific activities theoretically attainable for one iodine atom/molecule ACTH and for completely iodinated ACTH (four iodine atoms/molecule) are given in Table I. Because of the longer half-life of ${ }^{125} \mathrm{I}$ the theoretically attainable specific activities for ${ }^{125}$ I-labeled preparations are only $1 / 7$ as high as for ${ }^{181}$ I-labeled preparations.

Although ${ }^{125} \mathrm{I}$ is obtainable virtually free of other iodine isotopes, the isotopic abundance of ${ }^{181} \mathrm{I}$ produced by tellurium irradiation has not, since January 1966, exceeded $15-20 \%$ at the time of removal from the Union Carbide reactor at Sterling Forest (5). Although available only at monthly intervals, fission-produced ${ }^{131} \mathrm{I}$ from Oak Ridge has frequently shown an isotopic abundance of $30-35 \%$ at time of receipt in the laboratory (5). Table I also shows the concentrations of $\mathrm{ACTH}_{-}{ }^{125} \mathrm{I}$ and $\mathrm{ACTH}-{ }^{131} \mathrm{I}$, 
TABLE I

Specific Activities and Tracer Concentration of ACTH-131I and ACTH-195I for Equal Counting Rates

\begin{tabular}{|c|c|c|c|c|}
\hline & \multirow{2}{*}{$\begin{array}{c}\text { Average I } \\
\text { atoms } / \text { molecule }\end{array}$} & \multicolumn{2}{|c|}{ Initial specific activity } & \multirow{2}{*}{$\begin{array}{l}\text { Concentration of } \\
\text { ACTH-I for } \\
1,000 \mathrm{cpm} / \mathrm{ml}\end{array}$} \\
\hline & & $\begin{array}{l}\text { Carrier-free } \\
\text { I }\end{array}$ & $\begin{array}{c}\text { Available* } \\
\text { I }\end{array}$ & \\
\hline ACTH-131I & $\begin{array}{l}1 \\
4\end{array}$ & $\begin{array}{l}3,600 \mathrm{mc} / \mathrm{mg} \\
14,400\end{array}$ & $\begin{array}{l}1,100 \mathrm{mc} / \mathrm{mg} \\
4,400\end{array}$ & $\begin{array}{l}3.3 \mu \mu \mathrm{g} / \mathrm{ml} \\
0.83\end{array}$ \\
\hline ACTH-125I & $\begin{array}{l}1 \\
4\end{array}$ & $\begin{array}{r}500 \\
2,000\end{array}$ & $\begin{array}{r}500 \\
2,000\end{array}$ & $\begin{array}{l}1.4 \\
0.35\end{array}$ \\
\hline
\end{tabular}

* Available isotopic abundance: ${ }^{181} \mathrm{I} \simeq 30 \%$; ${ }^{125} \mathrm{I} \simeq 100 \%$.

$\ddagger$ In a sample counted $1 \mathrm{wk}$ after receipt of isotope in well-scintillation counter with $\gamma$-ray spectrometer set for photopeak of ${ }^{131} \mathrm{I}$ and $12-90 \mathrm{kv}$ for ${ }^{185} \mathrm{I}$. Counting efficiencies: $0.5 \times 10^{6} \mathrm{cpm} / \mu \mathrm{C}{ }^{131} \mathrm{I}, 1.5 \times 10^{6} \mathrm{cpm} / \mu \mathrm{C}{ }^{125} \mathrm{I}$.

labeled with one iodine atom/molecule, required to yield a counting rate of $1000 \mathrm{cpm} / \mathrm{ml}$ in a sensitive automatic scintillation well-counter 1 wk after receipt of the radioiodine, under optimal counting conditions. This table was calculated on the basis that ${ }^{101} \mathrm{I}$ is available with an isotopic abundance as great as $30 \%$ and that the maximal efficiency for counting ${ }^{125} \mathrm{I}$ in the usual well-type scintillation counter attached to a $\boldsymbol{\gamma}$-ray spectrometer is almost three times that for ${ }^{181} I$ under conditions providing optimal counting rates at low background levels.

Preparation and purification of ACTH-181 I and $A C T H{ }^{-25} I$. Immediately on receipt of ${ }^{181} I$ in the laboratory its isotopic abundance is determined, as previously described (6), from a radioautograph of a starch gel electrophoresis of crystalline insulin labeled at approximately 800 and $1500 \mathrm{mc} / \mathrm{mg}$. Only if the isotopic abundance exceeds $25-30 \%$ do we consider using the ACTH- ${ }^{181} \mathrm{I}$, which is prepared at the same time at a specific activity of about $1000-1200 \mathrm{mc} / \mathrm{mg}$, for an immunoassay.

We have previously described the preparation of $A C T H-{ }^{121} I$ and its purification by adsorption to and elution from cellulose columns or by addition to plasma and extraction therefrom with acetic acid- $\mathrm{HCl}$ mixtures (1). The following new procedure, 1 used for both ACTH- ${ }^{-21} I$ and $A C T H-{ }^{120} I$, is equally simple and recovers a large fraction of the undamaged labeled ACTH. The method of iodination is modified from that used by Hunter and Greenwood for growth hormone (7) : to 20 $\mu 10.25 \mathrm{M}$ phosphate buffer, $\mathrm{pH} 7.4$, in a flint glass test tube are added, in turn, approximately $2-2.5 \mathrm{mc}{ }^{181} \mathrm{I}$ or 0.8-1.0 mc ${ }^{180} \mathrm{I}, 2 \mu \mathrm{g}$ human ACTH $(2 \mu 1$ of a $1 \mathrm{mg} / \mathrm{ml}$ solution $), 15 \mu$ l chloramine $\mathrm{T}(3.5 \mathrm{mg} / \mathrm{ml}$ in $0.25 \mathrm{M}$ phosphate buffer), $20 \mu$ l sodium metabisulfite $(4.5 \mathrm{mg} / \mathrm{ml}$ in $0.25 \mathrm{M}$ phosphate buffer), and $1 \mathrm{ml}$ normal human plasma. Thorough mixing is accomplished by bubbling gently through the pipettes used to add the reagents and only a few seconds are allowed to elapse between steps after the addition of the hormone. The complete mixture is then immediately added to $5 \mathrm{mg}$ QUSO G32, micro fine precipitated silica granules, ${ }^{2}$ for purification by the same

1 Presented at the Annual Meeting of The Endocrine Society, Miami, Fla., 17 June 1967 (Abstr. 163).

2 Available from the Philadelphia Quartz Co., Philadelphia, $\mathrm{Pa}$. procedure as described earlier for the purification of labeled parathyroid hormone (8). The QUSO granules adsorb the undamaged labeled hormone but leave the unreacted iodide and the damaged fractions in solution. The granules pack well on centrifugation. After decantation of the supernatant plasma, followed by a single wash of the QUSO granules with $3 \mathrm{ml}$ distilled $\mathrm{H}_{2} \mathrm{O}$, the undamaged labeled ACTH is almost quantitatively eluted from the QUSO by shaking briefly with $0.5 \mathrm{ml} 40 \%$ acetone in $1 \%$ acetic acid; $1.5 \mathrm{ml}$ distilled $\mathrm{H}_{2} \mathrm{O}$ is added before centrifugation. The eluted labeled ACTH is tested for suitability in immunoassay by addition of appropriately small quantities to nonimmune plasma and to a $1: 50$ dilution of antiserum, known to be capable of binding essentially all of the tracer quantity of labeled ACTH within an hour or so. The mixtures are then examined for damaged fragments and for binding to antibody by paper strip chromatoelectrophoresis (2) or by adsorption to talcum powder (9) as described below. A good preparation may contain less than $5 \%$ damaged fragments and less than $15 \%$ unreacted iodide even before purification (Fig. $2 a$ ). The purified material should be essentially free of damaged components even if there is significant damage in the original preparation (Fig. $2 b$ ).

Adsorption of labeled ACTH to glass and damage to labeled ACTH; protection against adsorption and damage. Labeled ACTH has two important and troublesome characteristics: a strong tendency for adsorption to glassware (10) and a marked susceptibility to damage during incubation. We have tried various types of plastic tubes to avoid adsorption but without signal success; however, we have found that soft ("flint") glass is less adsorptive than hard ("borosilicate") glass and that siliconization significantly reduces adsorption. Nevertheless, it remains necessary to include a fairly high concentration of carrier protein if losses by adsorption are to be minimized. For this and other reasons, the incubations for assay are usually carried out in plasma diluted $1: 5$. As will be described below, the reaction of ACTH with the antibody may be partly inhibited at high salt concentration, so that the standard curve may be higher in diluted plasma than in whole plasma. However, since sensitivity is quite satisfactory at a plasma dilution of $1: 5$ and since the low concentrations of en- 


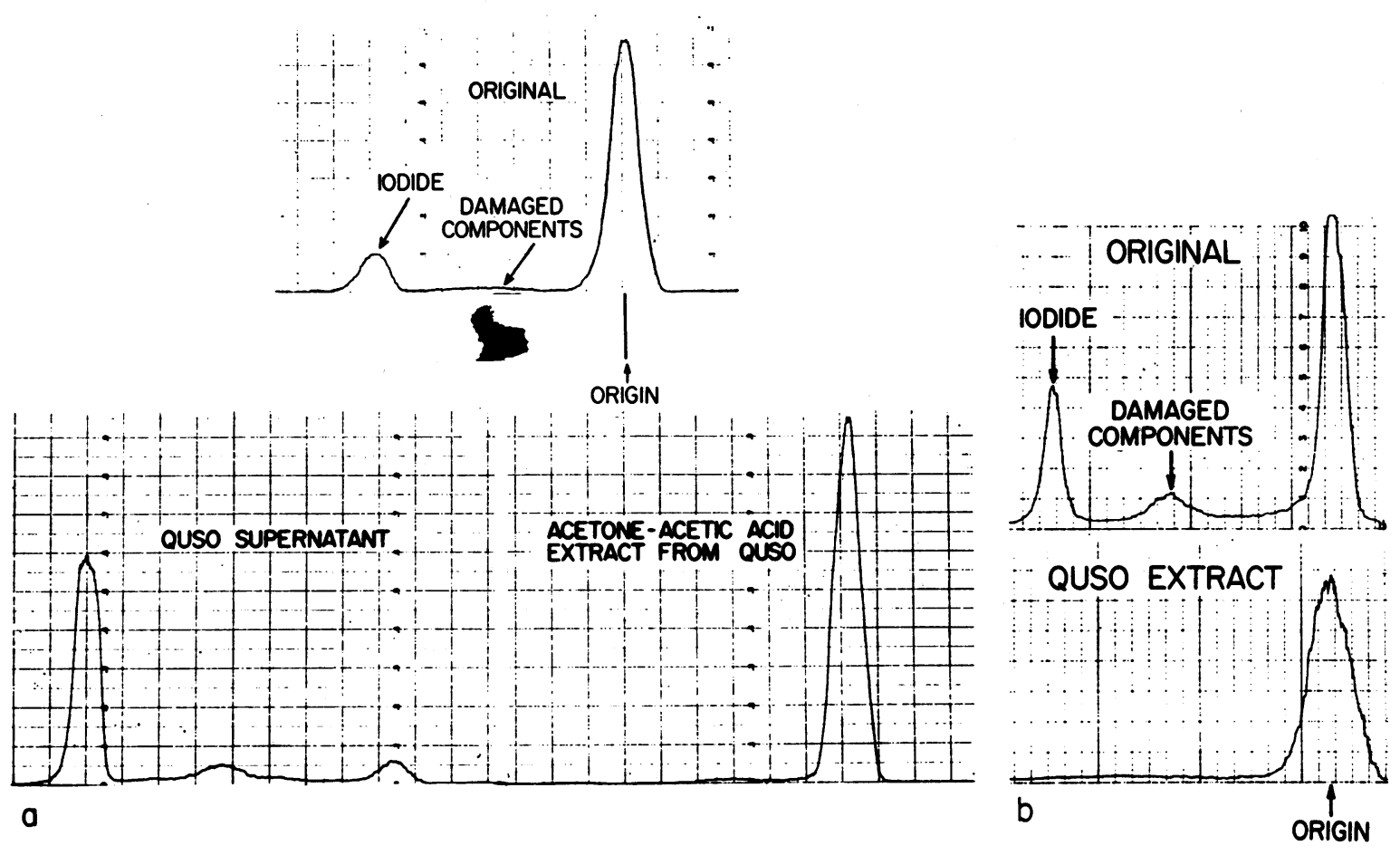

FIGURE 2 Scans of radioactivity on paper strip chromatoelectrophoretograms of labeled ACTH before and after purification with QUSO granules and of nonadsorbed QUSO supernatant. Whatman $3 \mathrm{MC}$ paper was used in these experiments and approximately $100 \mu \mathrm{l}$ bromphenol blue-stained plasma was added to the preparations before application to the paper strips. The paper strip showing the stained serum albumin is placed under the scan of the original unpurified preparation in $a$. The unpurified preparation shown in $b$ contained a larger fraction of damaged components. Unextracted radioiodide and damaged components that migrate with the plasma proteins do not adsorb to the paper strips at the site of application or to the QUSO granules.

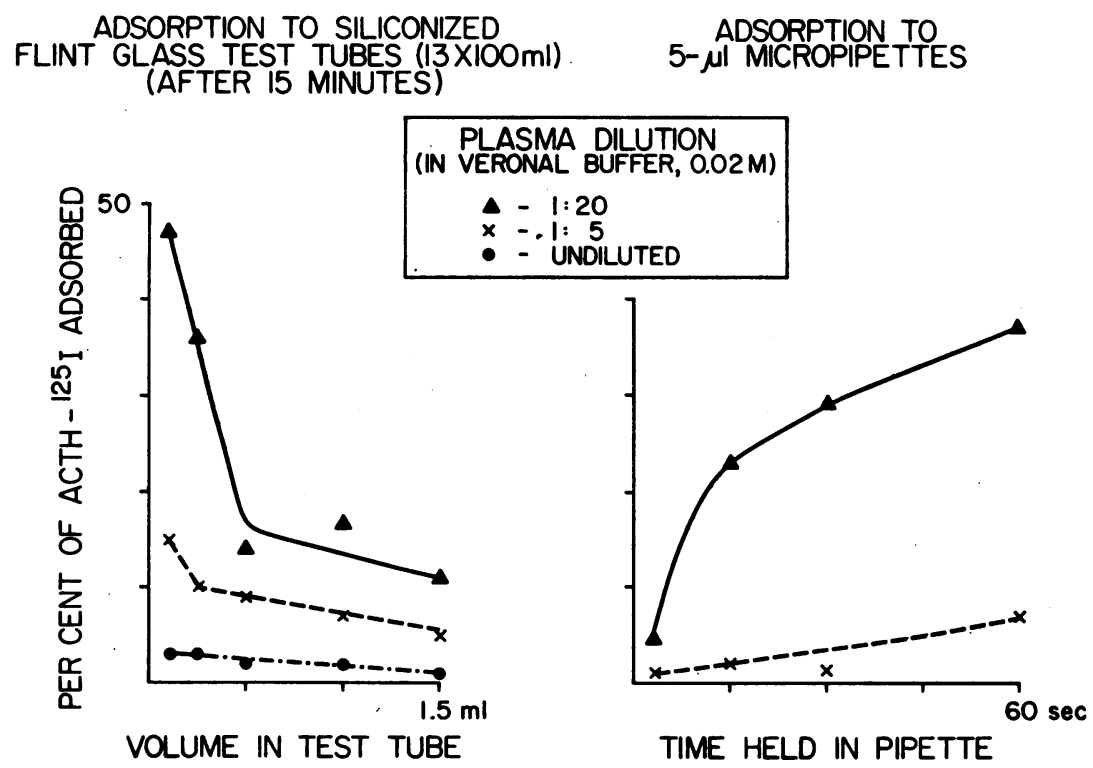

Figure 3 Adsorption of labeled human ACTH in plasma to glassware. After contents were removed test tubes were rinsed with $2.5 \mathrm{ml}$ water and pipettes were rinsed with a single wash before counting. 
dogenous plasma ACTH and the tendency for adsorption to glass set limits to the plasma dilution that can be tolerated, the conditions employed represent a convenient compromise among the various factors governing sensitivity. Since adsorption to glass increases as the ratio of surface to volume increases, only slight percentage losses are observed in a large full vessel standing quietly. However, a significant fraction of the ACTH present in small volumes in test tubes or pipettes may be rapidly lost to the glassware (Fig. 3). Adsorption is slower at $4^{\circ} \mathrm{C}$ than at room temperature and is significantly reduced at acid $\mathrm{pH}$.

It has been appreciated that damage to all labeled peptide hormones occurs on prolonged incubation in plasma and that correction for damage must be made in the radioimmunoassay (11). However, ACTH is prone to greater "incubation damage" than several of the other hormones. Indeed, Richards and Sayers (12) have shown that the biologic activity of ACTH incubated in plasma is lost within a few hours. Damage to ACTH- ${ }^{131} \mathrm{I}$ or ACTH- ${ }^{125} \mathrm{I}$ is reflected in the release of small amounts of free radioiodide and in the appearance of components that are no longer able to bind to antibody or of components that have otherwise lost such characteristics of the undamaged labeled ACTH as the ability to adsorb well to cellulose, talcum, or QUSO granules. Thus, in systems employing these media for separation of antibodybound and free ACTH, the damaged components appear with the nonadsorbed, antibody-bound fraction, whereas in double antibody systems they appear in the nonprecipitated free fraction.

It is known that the biologic activity of $\mathrm{ACTH}$ is lost on exposure to $\mathrm{H}_{2} \mathrm{O}_{2}$ (13), a result of oxidation of the methionine residue in position 4 (14), and after treatment with plasmin (fibrinolysin) (15), a proteolytic enzyme in plasma. To prevent oxidation of the methionine of labeled ACTH we had tried various thiols and found mercaptoethanol to be most effective in protecting against damage (1). However, since the addition of strong solutions of $\mathrm{H}_{2} \mathrm{O}_{2}$ to plasma does not significantly damage the labeled ACTH in plasma in the same way that incubation in plasma does, it appears possible that mercaptoethanol may protect labeled ACTH from incubation damage by inactivating certain disulfide-con-

TABLE II

Effect of Protective Agents on Stability of ACTH-131 I Added to 1:5Plasma and Incubated $16 \mathrm{hr}$ at $25^{\circ} \mathrm{C}$

\begin{tabular}{|c|c|c|}
\hline Protective agent & $\begin{array}{l}\text { Damaged } \\
\text { components }\end{array}$ & Iodide \\
\hline & \multicolumn{2}{|l|}{$\%$} \\
\hline A. None & 53 & 3 \\
\hline B. 6-Aminocaproic acid, $12.5 \mathrm{mg} / \mathrm{ml}$ & 36 & 2 \\
\hline C. Mercaptoethanol, $5 \mathrm{mg} / \mathrm{ml}$ & 23 & 3 \\
\hline D. Trasylol, $500 \mathrm{KIU} / \mathrm{ml}$ & 19 & 2 \\
\hline $\begin{array}{r}\text { E. Mercaptoethanol, } 5 \mathrm{mg} / \mathrm{ml} \\
+ \text { Trasylol, } 500 \mathrm{KIU} / \mathrm{ml}\end{array}$ & 2 & 2 \\
\hline
\end{tabular}

taining proteolytic enzymes. Whereas $50 \%$ or more of labeled ACTH may be damaged within a day, or even a few hours, when kept at $4^{\circ} \mathrm{C}$ in plasma diluted 1:5 without mercaptoethanol, the labeled hormone is quite stable for weeks when stored in acetone-acetic acid without mercaptoethanol (see below).

At high concentrations of mercaptoethanol there appears to be some inhibition of the antigen-antibody reaction but below a concentration of about $0.5 \%$ we have not observed inhibition. Also, mercaptoethanol, $0.5 \%$ produces some coagulation of whole plasma but not of a $1: 5$ dilution of plasma in $0.02 \mathrm{M}$ Veronal buffer. Incubation mixtures are therefore made up to contain about $0.35-0.4 \%$ mercaptoethanol. Additional protection is provided by certain inhibitors of proteolytic enzymes. In our hands, Amicar (6-amino-caproic acid, Lederle Laboratories, Pearl River, N. Y.), an inhibitor of plasminogen activation, has been only slightly protective even at fairly high concentrations. However, both pancreatic trypsin inhibitor and Trasylol (FBA Pharmaceuticals, Inc.), an inhibitor of trypsin and plasmin, derived from lung extracts, have been useful (Table II).

On the basis of the foregoing observations, conditions for routine assay have been set as follows. Incubation mixtures of $2.5 \mathrm{ml}$ are prepared in disposable flint glass tubes in which the plasma is diluted $1: 5$ in $0.02 \mathrm{M}$ Veronal buffer containing the following: mercaptoethanol, $0.35-0.4 \%$; Trasylol, $400-500 \mathrm{KIU} / \mathrm{ml}$; ACTH${ }^{131} \mathrm{I}$ or $\mathrm{ACTH}^{125} \mathrm{I}$, antiserum, and control (i.e. nonimmune) guinea pig serum at a final concentration of $1-2 \%$; the latter is included to prevent adsorption of antibody to the glass. Tubes are capped with parafilm to prevent loss of mercaptoethanol by evaporation. Mixtures are incubated at $4^{\circ} \mathrm{C}$. Under the conditions described, adsorption to the glass is negligible and incubation damage plus release of radioiodide should not exceed about $8-10 \%$ after 7 days but some plasmas are more damaging than others and the general level of damage varies slightly from one assay to another depending on the quality of the labeled ACTH. Although proteolytic enzymes appear to be partly, if not completely, responsible for incubation damage, we have frequently found that a higher concentration of plasma is somewhat protective. Thus, in the absence of any protective agents, labeled ACTH may suffer least damage in plasma diluted 1:20 but slightly greater damage in the same plasma diluted $1: 5$ or $1: 10$ than at $1: 2.5$ dilution. Whether this phenomenon is related to differential effects of dilution on endogenous enzymes and enzyme inhibitors in plasma or to other factors is not known.

As already noted, free labeled iodide as well as damaged labeled peptide components may appear after prolonged incubation. The release of radioiodide from the labeled hormone appears to be caused by two factors. Firstly, it seems likely that part of the iodide that appears is produced by dehalogenase activity in plasma since there is usually a greater amount of radioactive iodide after storage of the labeled ACTH in plasma than in $20 \%$ actone- $0.25 \%$ acetic acid (Fig. 4). Secondly, we have found that there is a more rapid appearance both 
of radioiodide and of altered labeled peptide components in stored solutions of $A C T H-{ }^{125} I$ than $A C T H-{ }^{131} I$ when labeled with the same number of iodine atoms per molecule (Fig. 4). This phenomenon is probably related to the fact that even when the average iodination level is only one iodine atom/molecule, a significant fraction (over $50 \%$ in the case of insulin- ${ }^{181} \mathrm{I}$ [6]) of the iodine is on molecules that contain more than one iodine atom. Thus, when all the iodine atoms are radioactive, as in ACTH- ${ }^{125}$ I, decay of a radioiodine atom on a molecule containing more than one iodine atom may result in disruption of the molecule and release of the other radioactive iodine atoms in the free form or attached to a peptide fragment. We have referred to this process as "decay catastrophe" (16). Since the isotopic abundance of the ${ }^{181} \mathrm{I}$ used is frequently only $15 \%$ or less, relatively fewer of the iodinated molecules at the same iodination level contain more than one radioactive iodine atom per molecule. Although the half-life of ${ }^{125} \mathrm{I}$ is 57 days and radioactive decay amounts to only about $8.5 \%$ during the 1 st wk, ${ }^{125} \mathrm{I}$ can be released in almost equal amounts from doubly labeled molecules and in almost twice this amount from triply labeled molecules during the same period. The progressive increase of damage with time tends to limit the useful shelf-life of the ${ }^{125}$ I-labeled hormone. However, even after 7 wk storage in acetone-acid, the undamaged fraction of ACTH- ${ }^{131}$ I was still capable of binding completely to ACTH antiserum (Fig. 5), but the damaged peptide fraction migrating with the $\alpha$-globulins did not bind to antibody.

Hormones. Several highly purified preparations of human ACTH, obtained through the generosity of Dr. C. H. Li and of Doctors A. Lerner and V. Upton, were used for labeling and as standard. The $\mathrm{Li}$ preparation was sent to us in September 1964 and was reported to contain $140 \mathrm{U} / \mathrm{mg}$. Preparation $8 \mathrm{~B}$ of Upton and
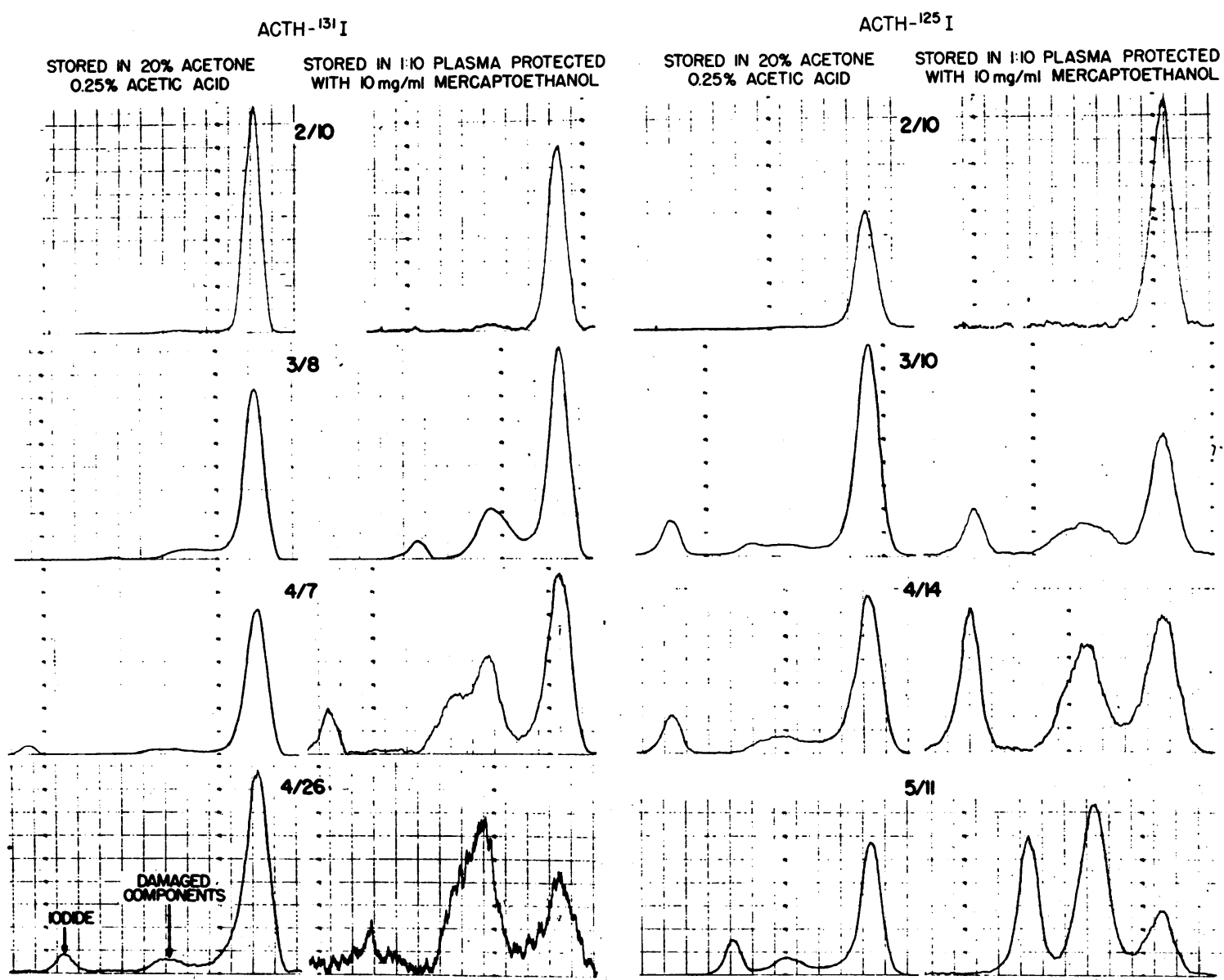

FIGURE 4 Chromatoelectrophoretograms of labeled ACTH preparations showing release of radioiodide and appearance of damaged components from ACTH- ${ }^{181} \mathrm{I}$ and $\mathrm{ACTH}-{ }^{125} \mathrm{I}$ (both labeled with an average of about 1 atom total iodine/molecule) after storage in solutions indicated. Both preparations were made and purified on 2/10. Portions were removed at intervals thereafter and added to $100 \mu \mathrm{l}$ plasma before application to paper strips for chromatoelectrophoresis. Note the greater damage in plasma than in acetone-acetic acid and the generally greater release of radioiodide from ACTH- ${ }^{125} \mathrm{I}$ in both storage media. 


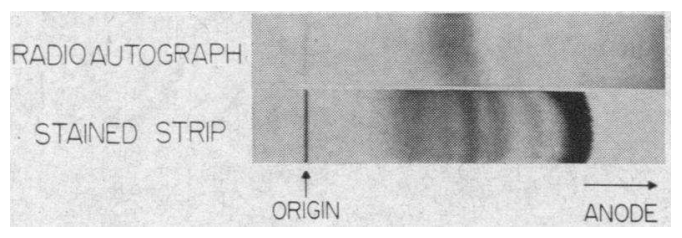

FIGURE 5 Radioautograph of paper electrophoretogram of labeled ACTH prepared 3/23/67 and added to immune plasma on 5/11/67. Binding of ACTH-181 I to antibody after $7 \mathrm{wk}$ storage of the labeled hormone in acetone-acetic acid. Note light radioactive band of damaged hormone in inter $\alpha$-region that does not bind to antibody. In nonimmune plasma undamaged $\mathrm{ACTH}{ }^{181} \mathrm{I}$ remained at origin.

Lerner was reported to contain $139 \mathrm{U} / \mathrm{mg}$. These cannot be distinguished immunochemically (Fig. $6 a$ ) but several other preparations, which are of lower biologic potency, are weaker immunochemically as well and were not used as standards for radioimmunoassay. Hormone was dissolved in $5 \times 10^{-8} \mathrm{M} \mathrm{HCl}$ at $1 \mathrm{mg} / \mathrm{ml}$ and an aliquot was further diluted successively in whole human plasma (previously tested and found to contain negligble amounts of ACTH) to concentrations of $10 \mu \mathrm{g} / \mathrm{ml}$ and $200 \mathrm{~m} \mu \mathrm{g} / \mathrm{ml}$ for use as standards. The latter solutions were divided among 10-20 vials, each containing $0.5 \mathrm{ml}$ and frozen immediately. Previous experience with losses by adsorption from solutions containing lesser concentrations of carrier protein led us to the storage of standards in whole plasma. Original stock solutions at $1 \mathrm{mg} / \mathrm{ml}$ were also divided among multiple vials which were frozen and melted when needed for iodination.

Preparation of standard solutions. For assay, a stock standard solution is prepared at $2.5 \mathrm{~m} \mu \mathrm{g} / \mathrm{ml}$ in plasma from hypopituitary subjects or from dexamethasonetreated normal subjects if tests revealed the complete absence of hormone in the latter. Plasma containing standard is then mixed with the hormone-free plasma in appropriate proportions to provide final concentrations ranging usually from $1 \mu \mu \mathrm{g} \mathrm{ACTH} / \mathrm{ml}$ to $200-500 \mu \mu \mathrm{g}$ $\mathrm{ACTH} / \mathrm{ml}$ in the final incubation mixtures.

Preparation of incubation mixtures. When final incubation volumes are $2.5 \mathrm{ml}, 500 \mu \mathrm{l}$ of each unknown plasma are pipetted into individual tubes. To all tubes containing standards or unknowns $50 . \mu 1$ labeled ACTH followed by $1.95 \mathrm{ml}$ diluted antiserum is then added using a semiautomatic, foot-operated dilutor ${ }^{8}$ that can process over 350 tubes per hour. The antiserum is usually prepared at $1: 100,000$ dilution in $0.02 \mathrm{M}$ Veronal buffer containing control guinea pig plasma and protective agents as described above. Labeled ACTH is prepared in the same diluent fortified by $20 \%$ hormone-free plasma to prevent adsorptive losses. Thus, the final concentration of antiserum is $1: 125,000$ and all tubes, standards and unknowns, contain plasma in the same final dilution (approximately $1: 5$ ) and all other reagents, except unlabeled ACTH, at identical concentrations. Control tubes for the deter-

3 York Instrument Corp., New York. mination of free radioiodide and damaged components are set up for each patient. Plasmas assayed at different dilutions are diluted in the hormone-free plasma. Mixtures are incubated at $4^{\circ} \mathrm{C}$ for 5-7 days. Under the conditions employed, equilibrium is not complete (i.e. maximum $\mathrm{B} / \mathrm{F}$ ratio is not achieved in tubes containing only the labeled $\mathrm{ACTH}$ ) before 4-5 days, as determined by daily analysis. Since mixtures containing lower ACTH concentrations require a longer time to reach maximal $\mathrm{B} / \mathrm{F}$ ratios than those with higher concentrations, the initial slope of the standard curve is sharpest when incubation is carried to equilibrium.

Separation of antibody-bound and free hormone. Separation is effected either by paper chromatoelectrophoresis (2) or by adsorption of the free hormone to talc (9). All tubes are kept at $4^{\circ} \mathrm{C}$ until separation is effected. When ACTH- ${ }^{125} \mathrm{I}$ is employed, only the talc separation is used since the counting efficiency for ${ }^{125} \mathrm{I}$ in automatic paper strip Geiger counters is very poor. Since it is inconvenient to apply more than $300-400 \mu \mathrm{l}$ to paper strips, the chromatoelectrophoretic technique is used only when ACTH- ${ }^{131}$ I can be prepared at a specific activity of $1000 \mathrm{mc} / \mathrm{mg}$ or greater. Otherwise it is difficult to obtain satisfactory counting rates with a suitably low tracer concentration.

Conditions for separation are as follows:

Paper strips: Whatman $3 \mathrm{MC}$ or Toyo (No. 514) paper strips, width $11 / 2$ inches; chromatoelectrophoresis in 0.05 M phosphate buffer, ${ }^{4}$ constant voltage $600 \mathrm{v}$. Suffi-

4 Veronal buffer, used for other hormones (2), inhibits, slightly, the adsorption of free labeled ACTH to the paper and tends to broaden the peak of free hormone at the origin.

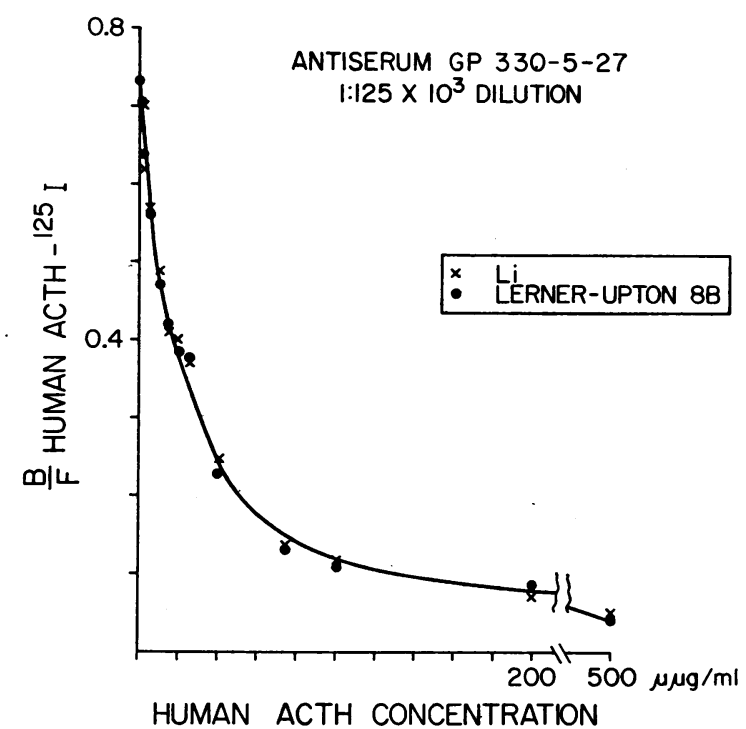

FIgURE $6 a$ Standard curve with human ACTH preparations of $\mathrm{C} . \mathrm{H}$. $\mathrm{Li}$ and of $\mathrm{A}$. Lerner and V. Upton. Mixtures prepared in hypopituitary plasma diluted $1: 5$ in $0.02 \mathrm{~m}$ Veronal buffer.

Radioimmunoassay of ACTH in Plasma 


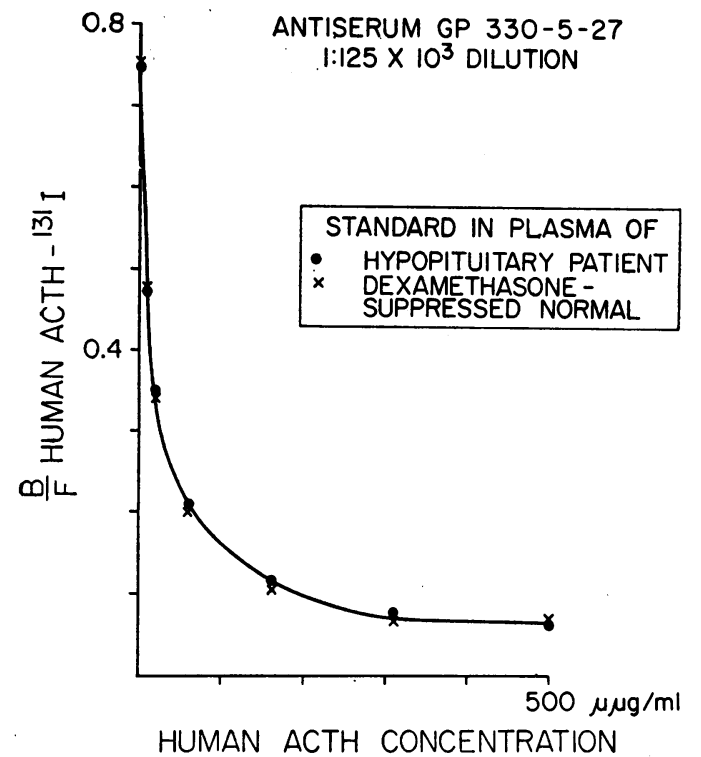

Figure $6 b$ Standard curve with Lerner-Upton human ACTH 8B prepared in 1:5 dilutions of plasmas from hypopituitary patient and dexamethasone-treated normal subject.

cient human plasma is added to incubation mixtures immediately before application to paper strips to bring the total volume of applied plasma to approximately 100-125 $\mu 1$ per strip.

All strips are counted twice in an automatic strip counter at a rate of $12 \mathrm{inches} / \mathrm{hr}$. Generally, at least 4000-5000 (usually more) counts are accumulated for each peak ( $B$ and $F$ ) of radioactivity.

Talc: One $50 \mathrm{mg}$ talc tablet is added to each incubation tube containing $2.5 \mathrm{ml}$ volume. After dissolution of the tablet, which requires about 1-2 min, the contents are briefly agitated by touching the bottom of the tube to a Vortex mixer; the tubes are then centrifuged for 25-30 $\mathrm{min}$ at $3000 \mathrm{rpm}$. Supernatant solutions containing antibody-bound hormone are decanted from the well-packed talc, to which the free hormone adsorbs. Supernatant solutions and talc precipitates are counted separately in an automatic well-counter attached to a $\gamma$-ray spectrometer; appropriate corrections are made for differences in geometry, where necessary. Tubes are counted at least twice for a sufficient time to collect at least 10,000 counts for each tube.

Miscellaneous. Data are processed with the aid of a Wang Loci -2 Computer, which is programmed to correct for damage in control mixtures and to correct for differences in geometry of talc and supernatant solutions counted in the well-counters.

Plasma concentrations of 17-OHCS were determined by Dr. Dorothy Krieger by a modification of the Sweat fluorescent method (17). Plasma glucose concentrations were determined in the AutoAnalyzer by the SomogyiNelson method (18); blood for these determinations was collected in tubes containing sodium fluoride.
Blood samples for ACTH assay were taken into heparinized syringes and centrifuged immediately in a refrigerated centrifuge. The separated plasma was stored at $-15^{\circ} \mathrm{C}$

\section{RESULTS}

Standard curves and sensitivity of assay. Although administration of dexamethasone did not always completely obliterate plasma ACTH, the standard curves obtained in plasmas with undetectable ACTH were essentially identical with those obtained in plasmas from cortisol-dependent patients with classical hypopituitarism (Figs. $6 b$, $c)$. With one exception, $B / F$ ratios in all hypopituitary subjects were essentially the same when the plasmas were assayed at the same dilution. When assays were carried out in hypopituitary plasmas at different plasma dilutions, the $B / F$ ratios were always higher in the more diluted plasma, at least between dilutions of about $1: 2$ to $1: 10$ (Fig. $6 c$ ). This difference appears to be principally, if not entirely, the result of a salt effect. If $\mathrm{NaCl}$ is added to the buffer or if the buffer strength is increased significantly, the curve obtained with plasma at high dilution approaches that obtained with more concentrated plasma. Standards prepared in hypopituitary plasma at 1:5 dilution and in 1\% albumin in the same buffer fortified with $0.18 \% \mathrm{NaCl}$ give similar curves (Fig. $6 d$ ).

It is well known that antigen-antibody complexes are dissociated at extremes of $\mathrm{pH}$. This is also true in the present system but we have not

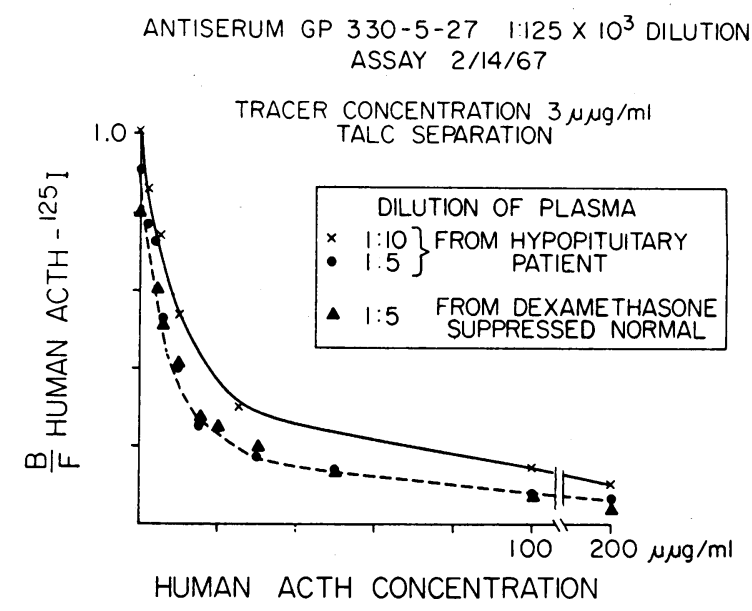

Figure $6 c$ Standard curves in 1:5 and 1:10 dilutions of plasma. 


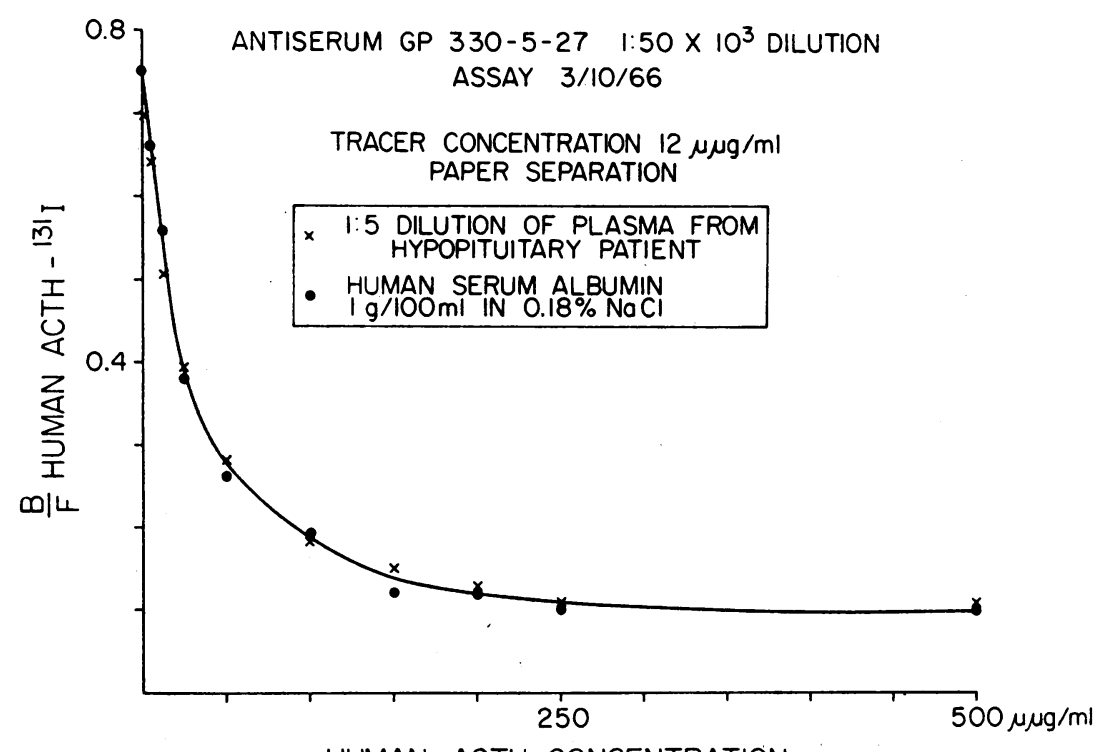

HUMAN ACTH CONCENTRATION

FIGURE $6 d$ Standard curve in 1:5 dilution of plasma in $0.02 \mathrm{M}$ Veronal and in $1 \%$ serum albumin plus $0.18 \% \mathrm{NaCl}$ in $0.02 \mathrm{M}$ Veronal.

noted any definite differences in plasma diluted $1: 5$ in phosphate buffer $0.02 \mathrm{M}, \mathrm{pH} 7.4$ and in Veronal buffer $0.02 \mathrm{M}, \mathrm{pH}$ 8.6.

When tracer concentrations did not exceed 1.5$2 \mu \mu \mathrm{g} / \mathrm{ml}$, the $\mathrm{B} / \mathrm{F}$ ratio usually showed a fall of about $50 \%$ from the initial ratio at a concentration of $10-20 \mu \mu \mathrm{g}$ unlabeled $\mathrm{ACTH} / \mathrm{ml}$ and a readily measurable decrease $(\geqq 20 \%)$ in $\mathrm{B} / \mathrm{F}$ ratio at $2 \mu \mu \mathrm{g} / \mathrm{ml}$ (Fig. $7 a$ ). In assays in which a tracer concentration of about $1-1.5 \mu \mu \mathrm{g} / \mathrm{ml}$ was used, a

ANTISERUM GP $330-5-27 \quad 1: 125 \times 10^{3}$ DILUTION

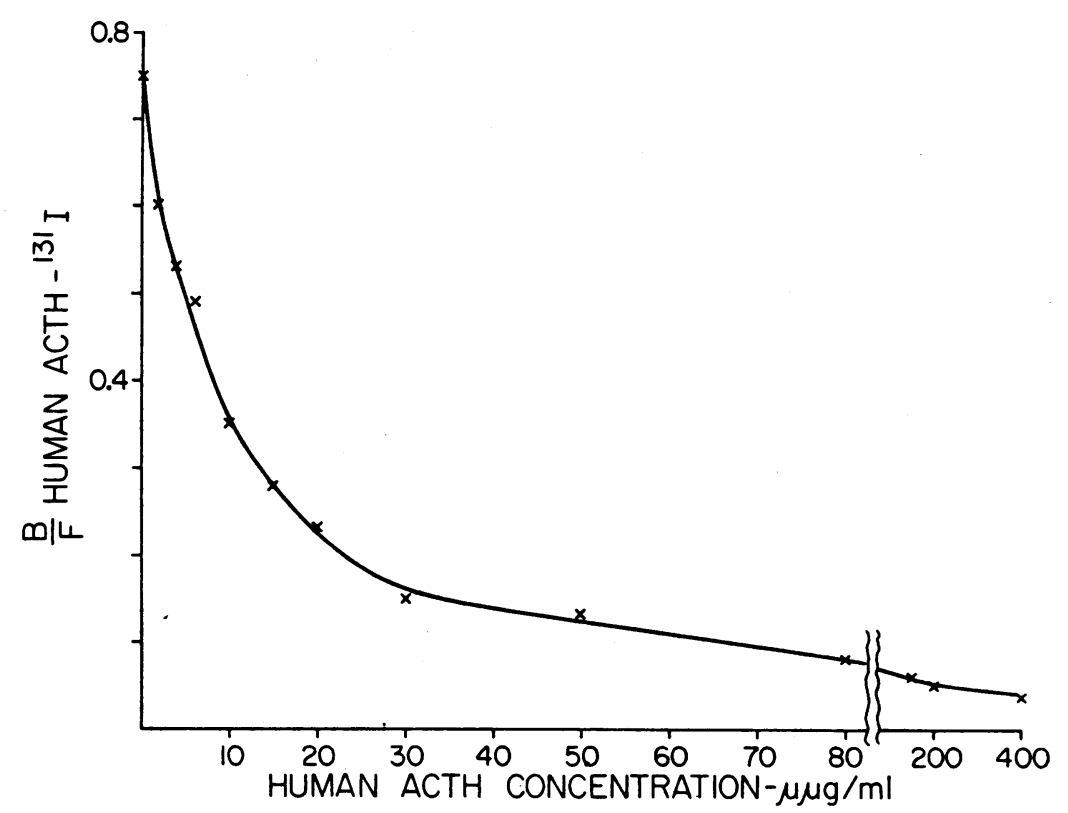

FIgURE $7 a$ Standard curve for human ACTH in 1:5 dilution of plasma. Tracer ACTH- ${ }^{121}$ I concentration $1.5 \mu \mu \mathrm{g} / \mathrm{ml}$. 
concentration of $1 \mu \mu \mathrm{g} / \mathrm{ml}$ could be detected. In plasmas assayed at $1: 5$ dilution, $5-10 \mu \mu \mathrm{g} \mathrm{ACTH/}$ $\mathrm{ml}$ whole plasma is therefore measurable, the lower value obtaining in the more recent assays.

There are some doubts concerning the immunochemical integrity of the labeled ACTH. In earlier studies with insulin-181I (19) and human growth hormone (HGH) - ${ }^{131} \mathrm{I}(20)$, we found no differences in immunoreactivity between labeled and unlabeled hormone; i.e. a tracer quantity of labeled hormone fortified by increasing amounts of unlabeled or labeled hormone at the same hormone concentrations gave similar curves. However, in similar experiments with labeled ACTH we have frequently observed that the $\mathrm{B} / \mathrm{F}$ ratio is lower when the same increment in ACTH concentration is provided by the labeled hormone than by the unlabeled hormone. The possibility that overiodination may be at fault is suggested by observations that selection of heavily iodinated insulin (6) or HGH (21) components results in diminished immunoreactivity compared to components of lower iodine numbers in the same preparations. Nevertheless, until proven otherwise with ACTH labeled at a low iodination level, the possiblity cannot be excluded that the preferential site for iodination is near or within the antigenic site for the antiserum used in these studies and that the iodine substitution reduces the imunoreactivity. It should be emphasized that whatever influence the lessened reactivity of ACTH may have on the sensitivity of the assay, it is, per se, irrelevant to the validity of the assay, which depends on the identity of reactivities, not of labeled and unlabeled ACTH, but only of standard pituitary $\mathrm{ACTH}$ and endogenous plasma ACTH.

Specificity of assay. As indicated above, the immunochemical reaction is sensitive to the ionic environment. However, since both standards and unknowns are incubated in plasma diluted similarly in the same buffer, there need be concern only for the possible effects of variations in the nonionic constituents of plasma. Of those plasma substances that are likely to vary widely, neither glucose nor urea, in concentrations found clinically, appears to influence the reaction.

A necessary, if not sufficient, condition for specificity is that the measured ACTH concentration in plasma decrease linearly with dilution of the plasma. This condition is met when plasma

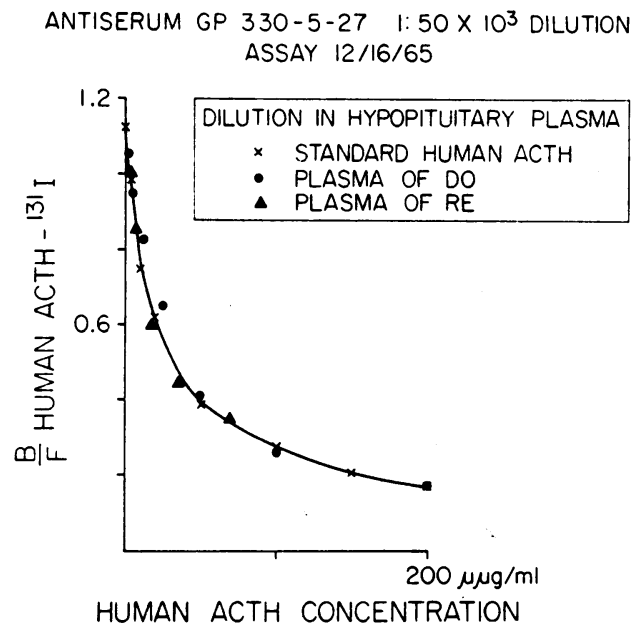

Figure $7 b$ Plasmas of two patients (Do. and Re.) with high concentrations of endogenous plasma ACTH were assayed at multiple dilutions by mixing with appropriate quantities of hypopituitary plasma. All tubes including standards contained plasma at $1: 2.5$ dilution in $0.02 \mathrm{M}$ Veronal buffer. The concentration in whole plasma was determined from the assay at $1: 2.5$ dilution (see Table III). The concentrations at other dilutions were then calculated from the dilution factors and plotted against the observed $B / F$ ratios.

containing a high concentration of hormone is progressively diluted in hypopituitary plasma and the points fall along the standard curve (Fig. $7 b$, Table III). This indicates that in this antiserum there is no discernible difference in immunochemical behavior of endogenous plasma hormone and purified extracted pituitary hormone added to plasma.

We have earlier (22) compared the cross-reactivities of certain fragments of ACTH and of the intact hormone in the antiserum used for assay. The hormonally inactive $11-24$ and the $C$ terminal 25-39 fragments reacted very poorly $(0.2-1 \%)$; the hormonally active 1-23 (tricosapeptide) and 1-24 (tetracosapeptide) fragments reacted more strongly but still no more than $5-10 \%$ as well as the intact hormone when crossreacting with the labeled intact hormone. Thus, if middle or $\mathrm{C}$ terminal fragments should be present in the blood stream they are not likely to be detected. If the tricosapeptide or tetracosapeptide are present they would be measured like ACTH by bioassay but would be grossly underestimated by immunoassay. $\beta$-MSH was previously found to be essentially inactive in another antiserum (1) and 
TABLE III

Endogenous ACTH in Unknown Plasmas Diluted in Hypopituitary Plasma

\begin{tabular}{|c|c|c|c|}
\hline \multirow[b]{2}{*}{$\begin{array}{l}\text { Plasma } \\
\text { dilution }\end{array}$} & & \multicolumn{2}{|c|}{$\underset{\mu \mu \mathrm{g} / \mathrm{ml}}{\mathrm{ACTH} \text { concentration, }}$} \\
\hline & & In sample & $\begin{array}{l}\text { Undiluted } \\
\text { plasma }\end{array}$ \\
\hline $1: 100$ & \multirow[t]{7}{*}{ Patient D. O. } & 5 & 500 \\
\hline $1: 40$ & & 9 & 360 \\
\hline $1: 20$ & & 18 & 360 \\
\hline $1: 10$ & & 47 & 470 \\
\hline $1: 5$ & & 110 & 550 \\
\hline \multirow[t]{2}{*}{$1: 25$} & & 200 & 500 \\
\hline & & \multicolumn{2}{|c|}{ Mean 460} \\
\hline $1: 100$ & \multirow[t]{6}{*}{ Patient R. E. } & 2 & 200 \\
\hline $1: 40$ & & 4 & 160 \\
\hline $1: 20$ & & 8 & 160 \\
\hline $1: 10$ & & 22 & 220 \\
\hline $1: 5$ & & 40 & 200 \\
\hline \multirow[t]{2}{*}{$1: 2.5$} & & 70 & 175 \\
\hline & & \multicolumn{2}{|c|}{ Mean 186} \\
\hline
\end{tabular}

was not tested in the antiserum used in the present study.

Perhaps the most important criteria for specificity of any assay are related to appropriate biologic behavior of the hormone under conditions known to be associated with stimulation or suppression of hormone secretion. Observations of this nature are reported subsequently.

\section{Reproducibility}

Reproducibility of $B / F$ ratios in same incubation sample when bound and free hormone are separated by paper chromatoelectrophoresis and by talc. We have previously shown good agreement between the two separation techniques (9). This is confirmed for most samples in another larger series here (Fig. 8a). However, in the plasma samples of one subject, $M$, which were quite damaging to the hormone, agreement was less satisfactory. When damage is excessive it is best to discard results or to judge them only semiquantitatively. Fortunately, such highly damaging plasmas as M's are rare under the protective conditions employed presently and have not been encountered among the last thousand samples assayed.

Reproducibility in duplicate separate incubation tubes prepared from the same plasma samples in the same assay. When duplicates of the same plasma samples were run as the first and last groups to be set up in an assay, results were generally in excellent agreement, except for the near zero values (Fig. $8 b$ ). We have found it desirable not only to run a number of such samples in duplicate at the beginning and end of each assay but also to divide the standards into two sets of alternating numbers, one to be set up at the beginning and the other at the end of the assay. The purpose of this procedure is to confirm that antibody concentration remained the same throughout the assay. In some earlier experiments we found that, because of the relatively large volume $(1000$ $2000 \mathrm{ml}$ ) of the antiserum-diluent mixture employed for an assay, the marked dilution of antiserum, and the dead space volume of the automatic dilutor, it was advisable not only to mix the antiserum-diluent mixture more thoroughly than was originally thought necessary, but also to circulate it through the dilutor for at least an hour, in order to avoid inhomogeneities in antibody concentration.

Reproducibility in different assays. When the same plasma sample was reassayed, the plasma being stored frozen between assays, the reproduci-

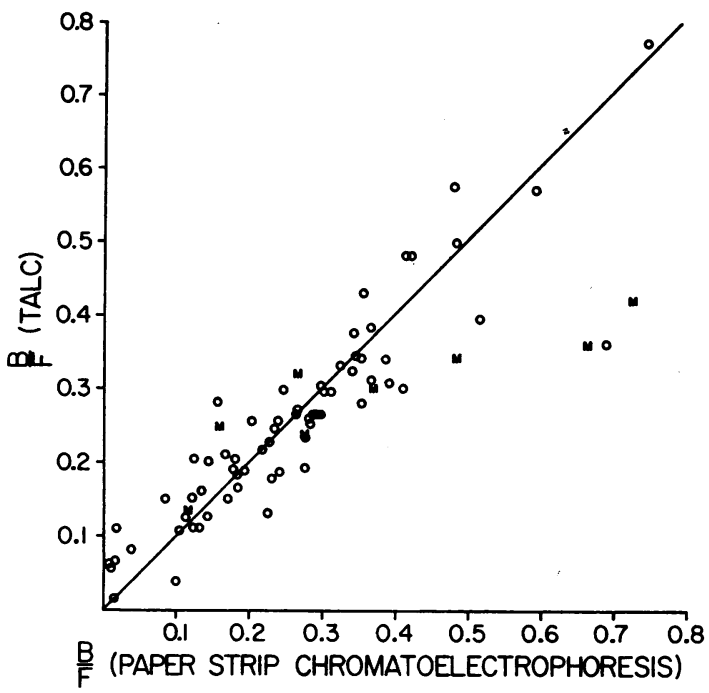

FIgURE $8 a$ Separation of bound and free labeled hormone by talc and paper strip chromatoelectrophoresis. $\mathrm{B} / \mathrm{F}$ ratios (corrected for damage in control tubes) observed in the same samples separated by chromatoelectrophoresis and by talc. Samples of $M$ were particularly damaging to the labeled hormone.

Radioimmunoassay of ACTH in Plasma 


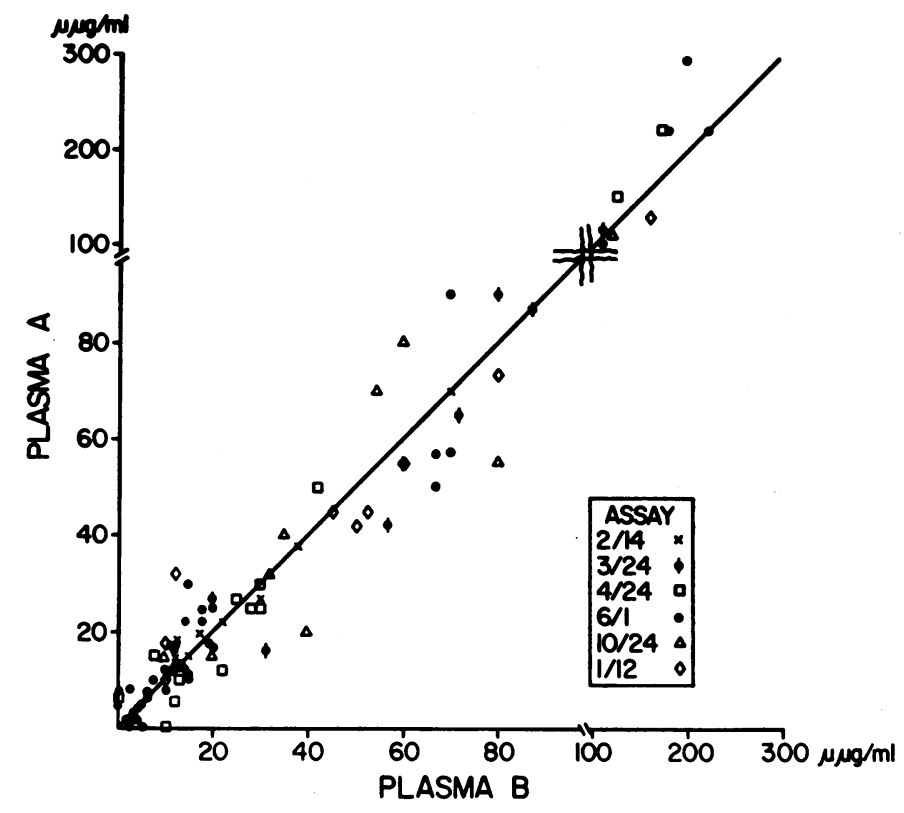

FIGURE $8 b$ Reproducibility of plasma ACTH concentrations in same assay. Hormone concentrations in duplicates of the same plasma samples determined in the same assay. bility (Fig. 8c) was less good than that observed between duplicates in the same assay (Fig. $8 b$ ). This was particularly true of the samples containing either very high or fairly low concentrations in the comparison assays of $4 / 24$ and $6 / 1$. This is at- tributable to the fact that the standard curve on the assay of $4 / 24$ was somewhat flatter initially and sharper at the end of the curve than was usually observed, which could be accounted for by random errors in one or two points of each of these

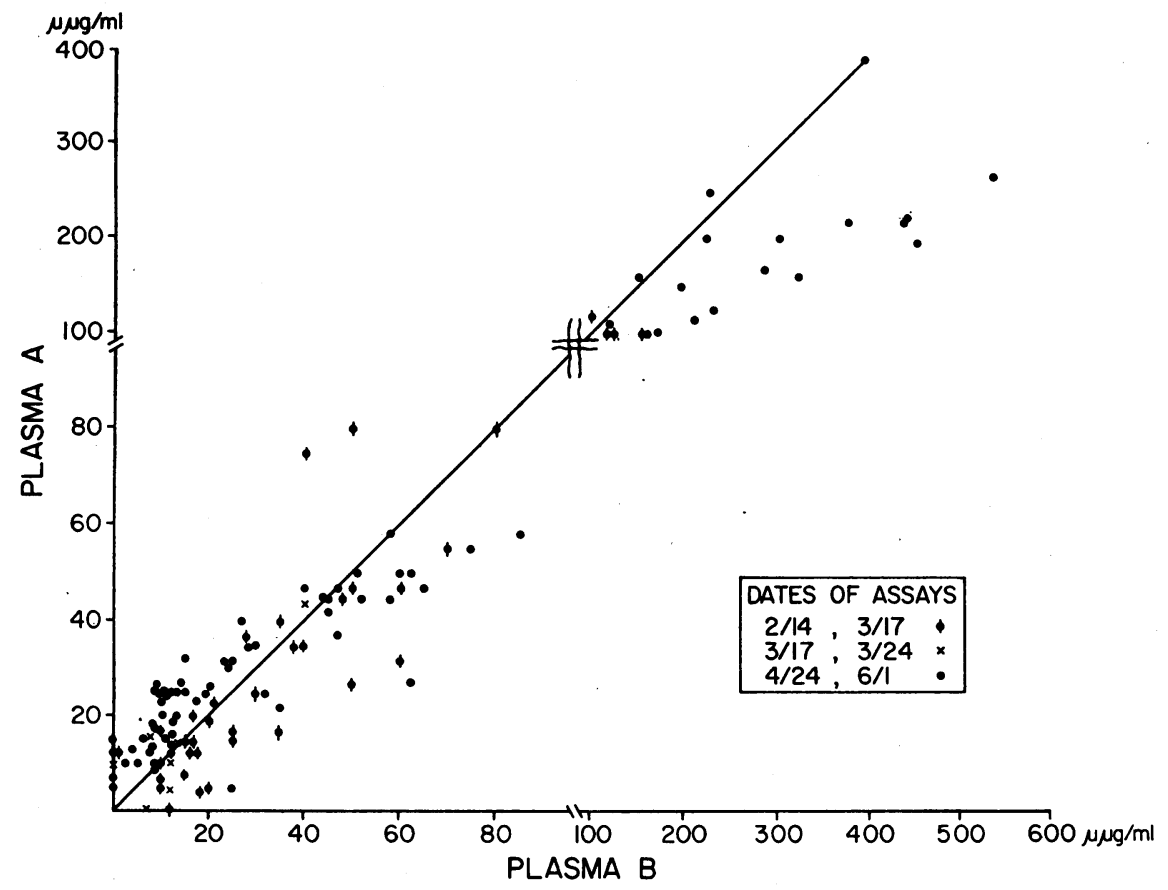

FIgURE $8 c$ Reproducibility of plasma ACTH concentrations in different assays. Hormone concentrations in duplicates of the same plasma samples determined in different assays. 
portions of the curves. Except for some near zero values, the largest percentage differences were observed with a group of plasma samples that assayed at about 8-12 $\mu \mu \mathrm{g} / \mathrm{ml}$ on the assay of $6 / 1$ and about $25 \mu \mu \mathrm{g} / \mathrm{ml}$ on the assay of $4 / 24$. To avoid such errors we now set up two standard curves for each assay (12 points each), either two separate hormone preparations (known to be equally potent) in the same hypopituitary plasma or one hormone preparation in two different hypopituitary plasmas.

Plasma ACTH in subjects without pituitary or adrenal disease

In hospital personnel and in clinic patients without serious illness, plasma concentrations at 8-10 a.m. only infrequently exceeded $50 \mu \mu \mathrm{g} / \mathrm{ml}$ and averaged $22 \mu \mu \mathrm{g} / \mathrm{ml}$ (Fig. 9). However, considerably higher concentrations were often observed in hospital patients with minor disorders as well as in more seriously ill patients (Fig. 9; see also Fig. 10). If the five values greater than 250 $\mu \mu \mathrm{g} / \mathrm{ml}$ are excluded, the average for this group of hospital patients is $45 \mu \mu \mathrm{g} / \mathrm{ml}$ and the median value is $25 \mu \mu \mathrm{g} / \mathrm{ml}$.

In a small group of nine normal subjects (Fig. 10) the mean plasma ACTH concentration at 10-11 p.m. was $9.6 \mu \mu \mathrm{g} / \mathrm{ml}$.

\section{Diurnal variations (Figs. 10-12)}

Although a well-marked circadian rhythm, similar to that reported for plasma cortisol, was not always evident in healthy personnel, the lowest values of the day were usually found between 6 p.m. and 11 p.m. (Fig. 10). Because of the inconvenience associated with blood sampling through the night, an early morning peak between 4 a.m. and 6 a.m. may have been missed in some of the

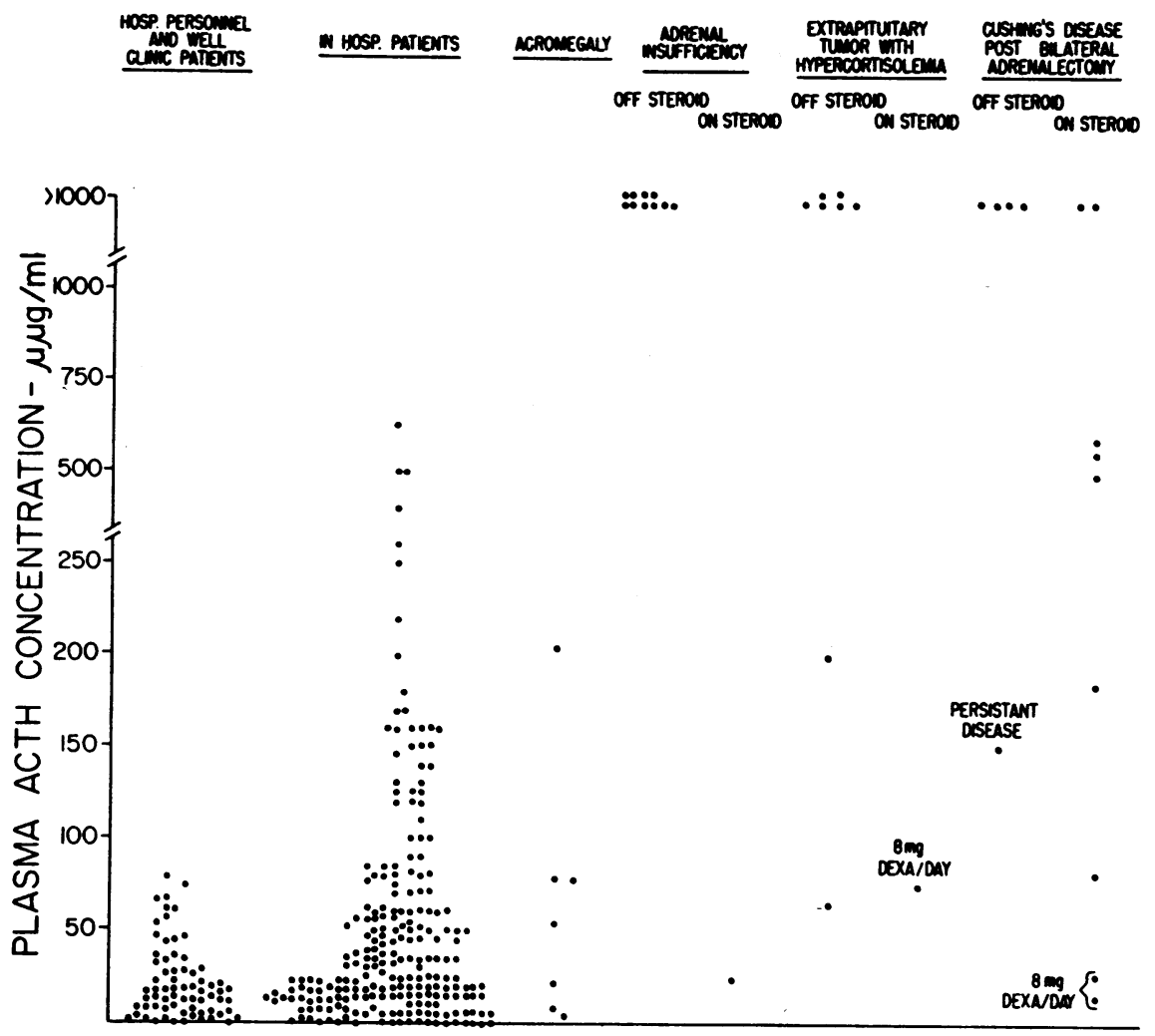

Figure 9 Plasma ACTH concentrations, 8-10 a.m. Cases shown here do not include those shown in the other figures except for the laboratory personnel in Fig. 10. The five in-hospital patients with the highest ACTH levels were all severely and acutely ill and carried the following diagnoses: Graves' disease, pneumonia and congestive heart failure, bronchogenic carcinoma, severe nonmalignant chest disease, and nephritis with uremia. 
PATIENTS

LABORATORY PERSONNEL

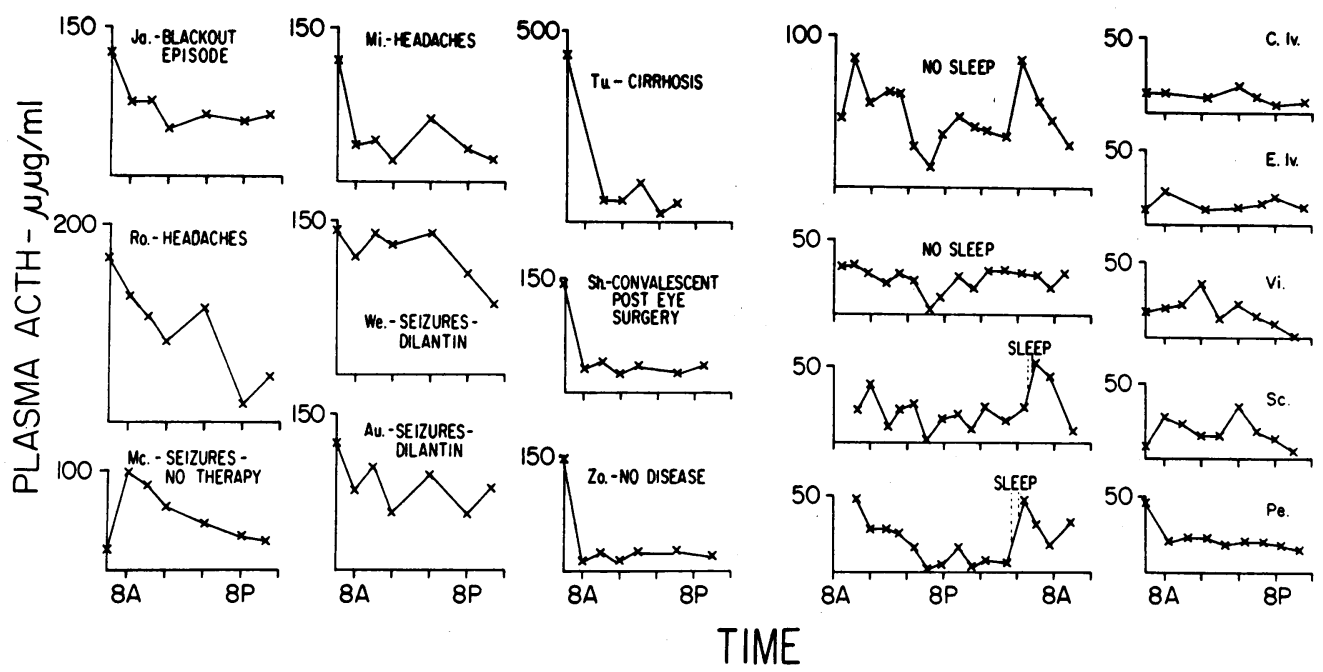

FIgURE 10 Plasma concentrations of ACTH throughout the day in healthy hospital personnel and in hospital patients without severe acute illness. The data of the four hospital personnel in the left column of that groud have been reported previously (22).

subjects. Although concentrations were frequently rather high at 6 a.m. -8 a.m. in hospital patients, including a group of subjects with a variety of obscure chronic neurologic disorders but without severe acute disability, a fall to less than 40-50 $\mu \mu \mathrm{g} / \mathrm{ml}$ later in the day was usually observed (Fig. 10; see also Table V B, C). Two of the neurologic patients (We. and Au.), who had persistently high ACTH concentrations during the day, had been receiving dilantin. In two other patients, not reported here, plasma ACTH concentrations were considerably higher while on dilantin therapy than prior to therapy.

In another group of healthy subjects, in whom plasma 17-OHCS concentrations every $4 \mathrm{hr}$ had been determined by Dr. Dorothy Krieger, a peak in plasma ACTH concentration was not always detected preceding the rise in plasma steroid (Fig. 11 , note particularly all studies on St.). Because of the short half-life of ACTH it is possible to miss the rise and fall in plasma ACTH concentration associated with a transient spurt in secretion when the interval between sampling is as long as $4 \mathrm{hr}$. To evaluate the temporal relationship between plasma ACTH and steroid levels, we took plasma samples at intervals of $1 / 2-1$ hr over one or two 24-hr periods from the subjects of Fig. 11 as well as from another subject. Comparison of plasma ACTH and steroid levels in these subjects reveals a good degree of parallelism in most cases (Fig. 12), the spikes in ACTH concentrations preceding the rises in cortisol concentration. The parallelism is most remarkable in Fr. $1 / 25$ and $\mathrm{Fu} .2 / 1$, but is singularly poor in St. in whom an anomalous relationship between the tropic hormone and the steroid had been observed on three previous occasions (Fig. 11). The range of ACTH levels varies more greatly than the range of plasma 17-OHCS concentrations among individuals.

\section{Effects of metyrapone (SU 4885) (Table IV)}

With the exception of C. Iv., who is a normal control, studies in this group were performed on hospital patients who were not severely ill; patient Lap., who was suffering from a postoperative wound infection, is an exception. When a single dose of metyrapone, $750 \mathrm{mg}$, by mouth, was given at 9 a.m. after two control samples taken $1 \mathrm{hr}$ apart, plasma ACTH concentrations changed little or continued to drop for 2-3 $\mathrm{hr}$ longer, after which there was usually at least a slight transient rise in concentration by the 3rd to 6 th hr (Table IV A). Repeated doses of metyrapone, $750 \mathrm{mg}$ every $4 \mathrm{hr}$, always resulted in very high ACTH concentrations by the following day.

When metyrapone was started at 6 p.m. at a 


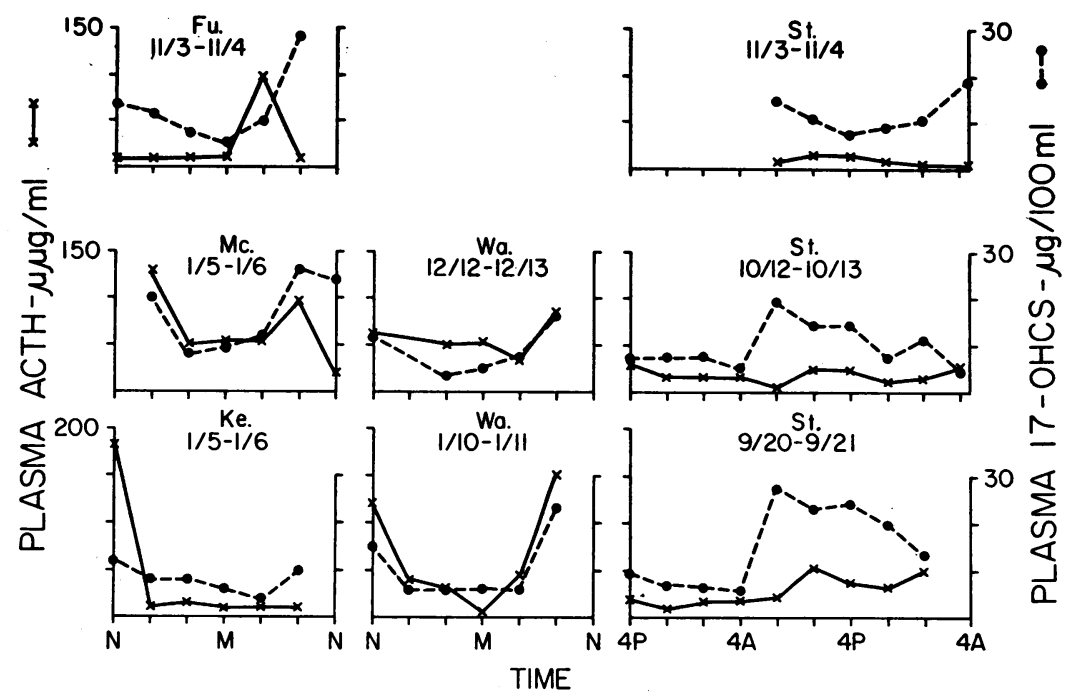

FIgURE 11 Plasma concentrations of ACTH and 17 OHCS throughout the day in normal subjects. Plasma samples in this and the following figure were supplied by Dr. D. Krieger who also performed the plasma 17-OHCS determinations.

dosage of $750 \mathrm{mg}$ every $2 \mathrm{hr}$ for three doses followed by $750 \mathrm{mg}$ every $4 \mathrm{hr}$ till the next morning, there were observed by 11 p.m. a distinct rise in plasma ACTH in only one subject and less definite rises in two other subjects of the eight studied on this regimen (Table IV B). By the following morning, however, plasma ACTH was elevated in all cases.

When metyrapone was given in doses of 750 $\mathrm{mg}$, by mouth, at 2 -hr intervals starting at 9 a.m., plasma concentrations usually began to rise within 2-3 $\mathrm{hr}$ reaching quite high levels during the early afternoon but tending, in three of the four cases, to decline by the evening (Table IV C). Similarly, when metyrapone was started at 4 p.m. plasma ACTH concentrations tended to fall by 11 p.m. even when an increase had been produced a few hours earlier. Again, in all cases, very high concentrations were observed on the following morning (Table IV D).

When metyrapone was given by continuous intravenous infusion over a $4 \mathrm{hr}$ period in the morning, four of the six patients showed a distinct rise in plasma ACTH by the end of the infusion or within $3 \mathrm{hr}$. The mean increase was $300 \pm 140 \%$.

\section{Effects of dexamethasone}

After institution of dexamethasone treatment, $0.5 \mathrm{mg}$ every $6 \mathrm{hr}$, plasma ACTH concentrations at 8 a.m. were frequently undetectable and almost always less than 10-20 $\mu \mu \mathrm{g} / \mathrm{ml}$, even when metyrapone stimulation had been carried out the previous day (Table IV B). Patient Lap. (Table IV B), referred to above, is an exception.

In a patient (J. F.) whose plasma ACTH had risen from 20 to $325 \mu \mu \mathrm{g} / \mathrm{ml}$ after 1 day's treatment with metyrapone ( $750 \mathrm{mg}$ every $6 \mathrm{hr}$ ), a single oral dose of $2 \mathrm{mg}$ of dexamethasone produced a sharp fall in plasma ACTH to $19 \mu \mu \mathrm{g} / \mathrm{ml}$ in $33 / 4$ hr. Under continued dexamethasone treatment $(0.5 \mathrm{mg}$ every $4 \mathrm{hr}$ ) plasma ACTH remained at less than $12 \mu \mu \mathrm{g} / \mathrm{ml}$ for the next $20 \mathrm{hr}$ in spite of continued treatment with metyrapone $(750 \mathrm{mg}$, by mouth, every $4 \mathrm{hr}$ ).

Effects of "stressful" stimuli (Table V A, Fig. 13)

Surgery (Table $V A$ ). Plasma ACTH concentrations were frequently high even preoperatively but were generally much higher postoperatively in patients given general anesthesia even though the latter samples were obtaind later in the day. No rise in plasma ACTH was observed postoperatively in two patients who had undergone surgery under spinal anesthesia.

Electric shock therapy (EST) (Table $V B$ ). In a group of patients undergoing EST for various psychodepressive disorders, a sharp transient rise

Radioimmunoassay of ACTH in Plasma

2739 
TABLE IV

Effects of Metyrapone and Dexamethasone on Plasma ACTH Concentrations $(\mu \mu \mathrm{g} / \mathrm{ml})$

\begin{tabular}{|c|c|c|c|c|c|c|c|c|c|c|}
\hline \multirow[b]{2}{*}{ Subject } & \multicolumn{8}{|c|}{$\begin{array}{l}\text { A. Metyrapone } 750 \mathrm{mg} \text { p.o. at } 9 \text { a.m. and } \mathrm{q} 4 \mathrm{hr} \text { from } 3 \text { p.m.-7 a.m. } \\
\text { Day } 1\end{array}$} & \multicolumn{2}{|c|}{ Day 2} \\
\hline & 8 a.m. & 9 a.m. & 10 a.m. & 11 a.m. & Noon & 1 p.m. & 2 p.m. & 3 p.m. & 8 a.m. & 3 p.m. \\
\hline Ha. & $>1000$ & 175 & 25 & 50 & 70 & 115 & 140 & 140 & 50 & 300 \\
\hline Re. & 40 & 90 & 55 & 55 & 100 & 80 & 70 & 60 & $>1000$ & 200 \\
\hline Mim. & 25 & 15 & 20 & 15 & 20 & 50 & 30 & 70 & $>1000$ & $>1000$ \\
\hline Go. & 35 & 50 & 40 & 40 & 70 & 30 & 25 & 30 & 180 & 70 \\
\hline Gel. & 40 & 40 & 50 & 50 & 70 & 65 & 60 & 70 & 200 & 60 \\
\hline Sc. & 20 & 20 & 20 & 20 & 15 & 90 & 15 & 15 & 125 & $>1000$ \\
\hline Mis. & 10 & 35 & 15 & 15 & 20 & 55 & 60 & 30 & 750 & 220 \\
\hline De. & 70 & 40 & 25 & 40 & 60 & 50 & 20 & 40 & 1000 & 500 \\
\hline Lab. & 60 & 40 & 45 & 95 & 105 & - & - & 1000 & 250 & 250 \\
\hline $\mathrm{Bi}$. & 65 & 95 & 90 & 130. & 110 & 125 & 150 & 95 & 1000 & 300 \\
\hline
\end{tabular}

B. Metyrapone $750 \mathrm{mg}$ p.o. q $4 \mathrm{hr}$ from 6 p.m. day 1 to 6 a.m. day 2 followed by dexamethasone $1 \mathrm{mg}$ p.o. $\mathrm{q} 6 \mathrm{hr} 9$ a.m. day 2 to 3 a.m. day 3

\begin{tabular}{|c|c|c|c|c|c|c|c|c|}
\hline \multirow[b]{2}{*}{ Subject } & \multicolumn{6}{|c|}{$\begin{array}{c}1 \mathrm{mg} \text { p.o. } \mathrm{q} 6 \mathrm{hr} 9 \text { a.m. day } 2 \text { to } 3 \text { a.m. day } 3 \\
\text { Day } 1\end{array}$} & \multirow{2}{*}{$\frac{\text { Day } 2}{8 \text { a.m. }}$} & \multirow{2}{*}{$\frac{\text { Day } 3}{8 \text { a.m. }}$} \\
\hline & 6 a.m. & 8 a.m. & Noon & 6 p.m. & 8 p.m. & 11 p.m. & & \\
\hline Lin. & 230 & 50 & 30 & 20 & 20 & 45 & 500 & 10 \\
\hline Lap. & 160 & 130 & 120 & 140 & - & 140 & 300 & 90 \\
\hline Bas. & 10 & 15 & 45 & 10 & 15 & 35 & 250 & 10 \\
\hline Arn. & 50 & 40 & 30 & 30 & - & 15 & 100 & 0 \\
\hline Mil. & 100 & 180 & 70 & 55 & 50 & 130 & 100 & 10 \\
\hline De G. & 55 & 25 & 30 & 10 & 10 & 10 & 300 & 10 \\
\hline New. & 70 & 55 & 50 & 30 & 25 & 20 & 200 & 15 \\
\hline Hat. & 60 & 50 & 40 & 60 & 30 & 20 & 130 & 5 \\
\hline
\end{tabular}

C. Metyrapone $750 \mathrm{mg}$ p.o. q 2 hr 9 a.m.-11 p.m.; 3 a.m., 7 a.m.

\begin{tabular}{|c|c|c|c|c|c|c|c|c|c|c|c|c|c|}
\hline \multirow[b]{2}{*}{ Subject } & \multicolumn{11}{|c|}{$\begin{array}{l}\text { C. Metyrapone } 750 \mathrm{mg} \text { p.o. q } 2 \text { hr } 9 \text { a.m. }-11 \text { p.m.; } 3 \text { a.m., } 7 \text { a.m. } \\
\qquad \text { Day } 1\end{array}$} & \multicolumn{2}{|c|}{ Day 2} \\
\hline & 8 a.m. & 9 a.m. & 10 a.m. & 11 a.m. & Noon & 1 p.m. & 2 p.n. & 3 p.m. & 6 p.m. & 8 p.m. & 11 p.m. & 8 a.m. & 9 a.m. \\
\hline K. T. & 230 & 175 & 45 & 90 & 110 & 100 & 115 & 175 & 250 & 135 & 10 & 170 & 470 \\
\hline G. S. & 110 & 57 & 40 & 125 & 170 & 175 & 160 & 100 & 180 & 58 & 225 & 700 & 700 \\
\hline E. M. & 48 & 5 & 10 & 15 & 27 & 50 & 30 & 25 & 150 & 135 & 95 & - & 425 \\
\hline C. Iv. & 0 & 23 & 43 & 70 & 43 & 80 & 150 & 175 & 80 & 15 & 25 & 185 & 280 \\
\hline
\end{tabular}

D. Metyrapone 750 mg p.o. q 2 hr 4 p.m.-10 p.m.; 2 a.m., 6 a.m.

\begin{tabular}{|c|c|c|c|c|c|c|c|c|c|c|c|}
\hline \multirow[b]{2}{*}{ Subject } & \multicolumn{9}{|c|}{ Day 1} & \multicolumn{2}{|c|}{ Day 2} \\
\hline & 3 p.m. & 4 p.m. & 5 p.m. & 6 p.m. & 7 p.m. & 8 p.m. & 9 p.m. & 10 p.m. & 11 p.m. & 8 a.m. & 9 a.m. \\
\hline L. P. & 40 & 20 & 18 & 35 & 35 & 30 & 35 & 90 & 20 & 200 & 500 \\
\hline W. M. & 45 & 55 & 35 & 28 & 80 & 125 & 115 & 110 & 55 & 430 & 750 \\
\hline J. E. & 100 & 70 & 55 & 115 & 200 & 115 & 160 & 180 & 175 & 440 & - \\
\hline C. D. & 20 & 15 & 15 & 35 & 0 & 40 & 30 & 25 & 30 & 250 & 200 \\
\hline
\end{tabular}

in plasma ACTH characteristically occurred within 5-10 min of the shock, after which concentrations fell precipitously and remained below preshock levels. It appeared that ACTH secretion was suppressed after the initial stimulation.

It may be noted that the control values averaged $75 \mu \mu \mathrm{g} / \mathrm{ml}$, which was somewhat higher than the average concentration of $45 \mu \mu \mathrm{g} / \mathrm{ml}$ for other hos- pital patients, a result perhaps attributable to the apprehension associated with anticipation of the treatment.

Hypoglycemia. When a fall in plasma glucose to less than $50 \mathrm{mg} / 100 \mathrm{ml}$ was induced by intravenous administration of insulin, $0.1 \mathrm{U} / \mathrm{kg}$ body weight, plasma ACTH uniformly rose sharply and then fell rapidly again as blood glucose rose (Fig. 
TABLE V

Effects of Certain Stresses in Plasma ACTH Concentration ( $\mu \mu \mathrm{g} / \mathrm{m} \iota)$

\begin{tabular}{|c|c|c|c|c|c|c|c|}
\hline \multirow[b]{2}{*}{ Patient } & \multirow[b]{2}{*}{ Operation } & \multicolumn{2}{|c|}{$\begin{array}{l}\text { A. Surgery } \\
\text { Preoperation }\end{array}$} & \multicolumn{2}{|c|}{ Immediate postoperation } & \multicolumn{2}{|c|}{$24 \mathrm{hr}$ after preoperation } \\
\hline & & Time & $\begin{array}{l}\text { Concen- } \\
\text { tration }\end{array}$ & Time & $\begin{array}{l}\text { Concen- } \\
\text { tration }\end{array}$ & Time & $\begin{array}{l}\text { Concen- } \\
\text { tration }\end{array}$ \\
\hline & & & $\mu \mu g / m l$ & & $\mu \mu g / m l$ & & $\mu \mu g / m l$ \\
\hline \multicolumn{8}{|c|}{ General anesthesia } \\
\hline R. T. & Arthrotomy & $8: 15$ a.m. & 115 & $11: 15$ a.m. & 320 & $8: 55$ a.m. & 20 \\
\hline V. A. & Bile duct exploration & $8: 15$ & 10 & 3:40 p.m. & 40 & $8: 25$ & 15 \\
\hline F. G. & Cholecystectomy & $8: 00$ & 115 & $2: 00$ & 280 & $9: 50$ & 0 \\
\hline H. G. & Herniorrhaphy & $8: 15$ & 75 & $3: 30$ & 150 & $9: 20$ & 70 \\
\hline C. McG. & 1. nephrectomy & $8: 20$ & 10 & 3:00 & 175 & $9: 00$ & 25 \\
\hline F. A. & Subtotal thyroidectomy & $8: 35$ & 250 & $12: 10$ & 500 & $9: 30$ & 135 \\
\hline W. McD. & Right lower lobectomy & $9: 15$ & 85 & $12: 15$ & 45 & $8: 15$ & 45 \\
\hline A. A. & Craniotomy & $8: 25$ & 180 & $1: 45$ & 130 & $8: 40$ & 160 \\
\hline D. A. & $\begin{array}{l}\text { r. adrenalectomy in } \\
\text { patient with Cushing's } \\
\text { syndrome previously } \\
\text { subjected to } 1 . \text { adrenal- } \\
\text { ectomy, } 75 \text { mg corti- }\end{array}$ & & & & & & \\
\hline & sone q $6 \mathrm{hr}$ & $9: 00$ & 65 & $11: 15$ a.m. & 275 & $9: 00$ & 65 \\
\hline \multicolumn{8}{|c|}{ Spinal anesthesia } \\
\hline M. B. & Prosthesis 1. hip & $8: 20$ & 250 & $12: 25$ p.m. & 65 & $9: 10$ & 20 \\
\hline H. T. & Herniorrhaphy & $10: 00$ & 60 & $1: 15$ & 90 & $8: 45$ & 80 \\
\hline
\end{tabular}

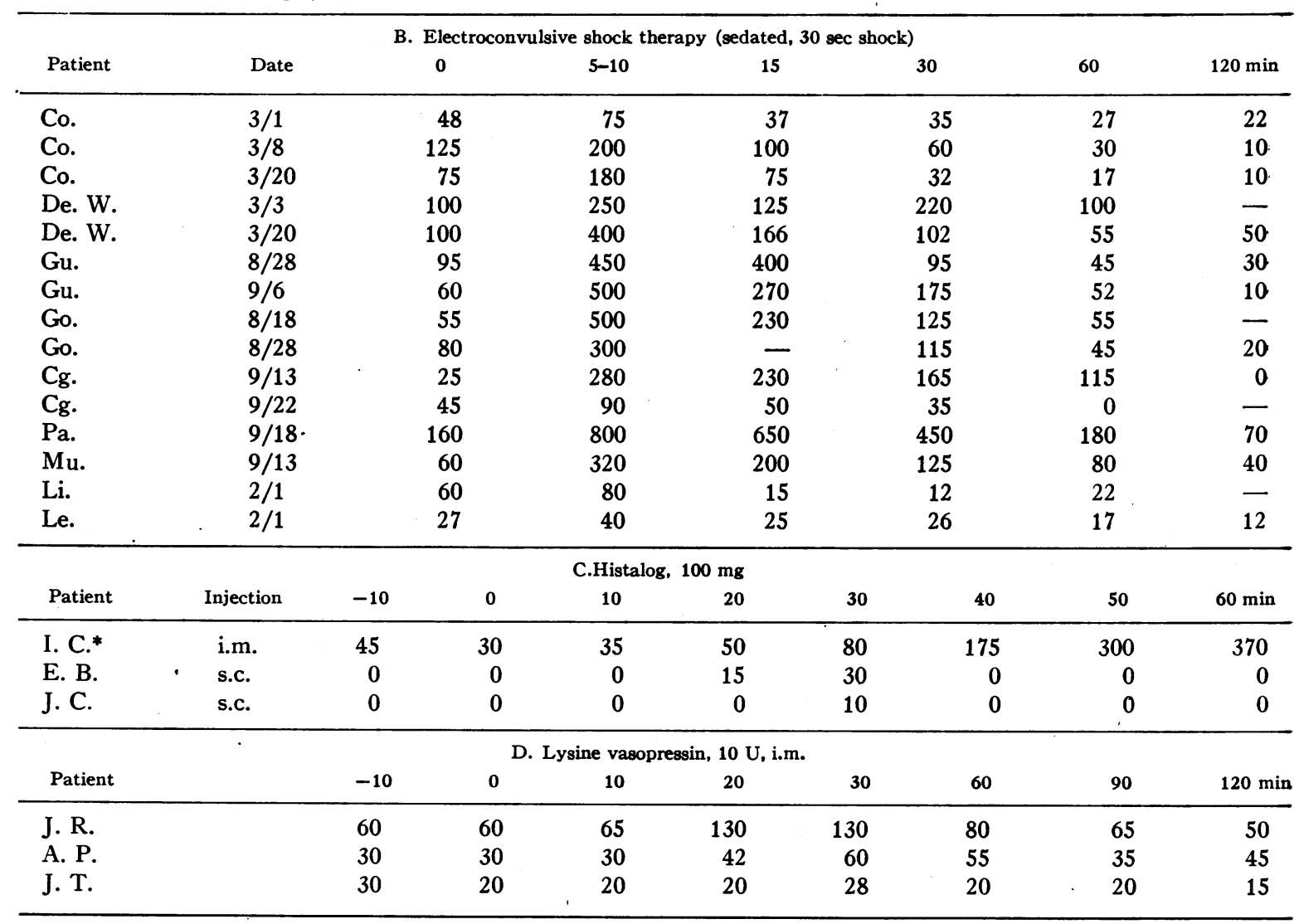

* Complained of headache $(15 \mathrm{~min})$ and abdominal pain $(30 \mathrm{~min})$. 


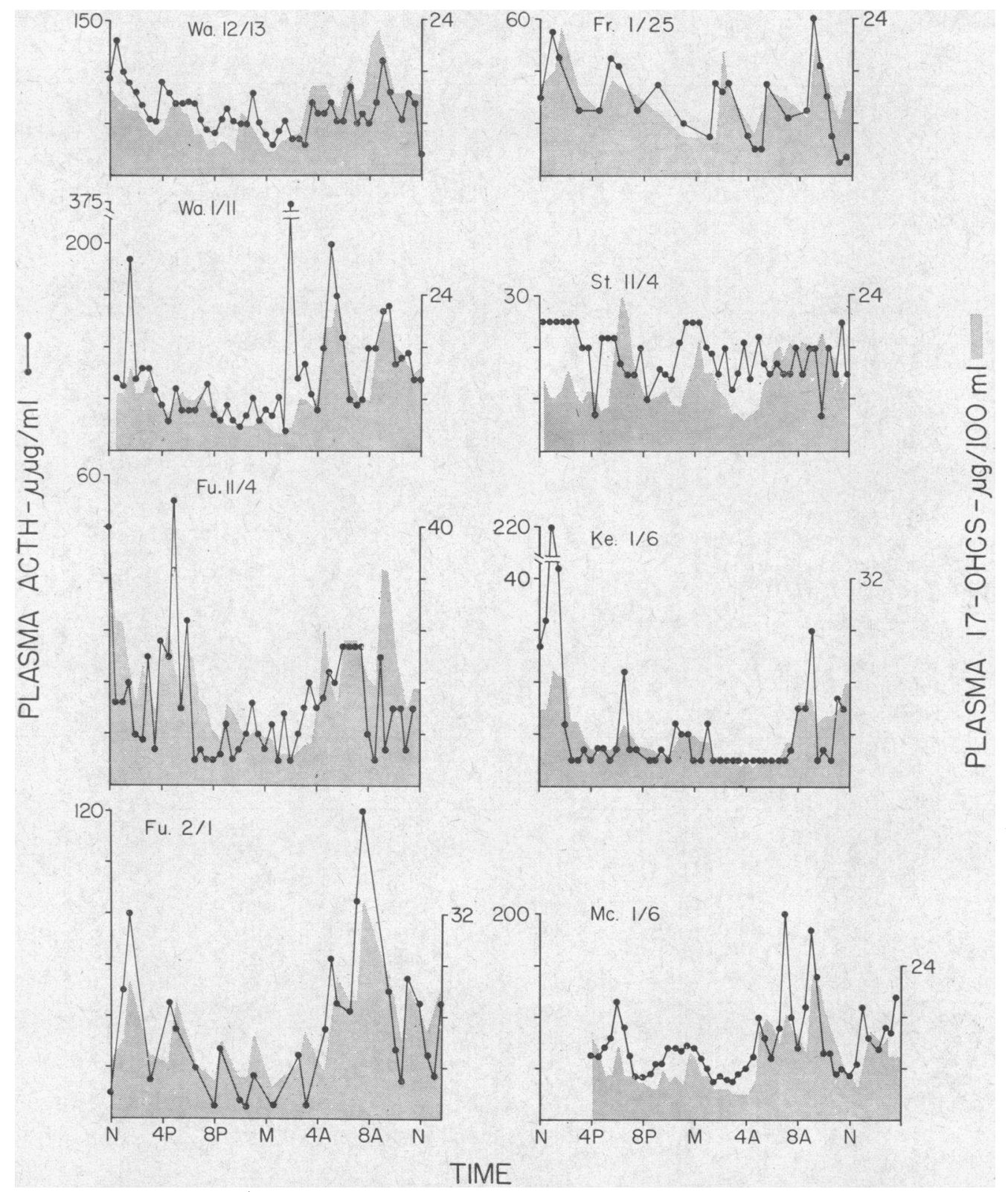

FIGURE 12 Plasma concentrations of ACTH and 17-OHCS throughout the day in normal subjects.

13). However, on the subsequent decline in plasma ACTH the concentration rarely fell below control levels. In two nondiabetic subjects in whom the lowest plasma glucose levels achieved were 51 $\mathrm{mg} / 100 \mathrm{ml}$ (F.E.) and $55 \mathrm{mg} / 100 \mathrm{ml}$ (S.E.) and in one diabetic subject (R.O.) whose plasma glucose concentration fell $100 \mathrm{mg} / 100 \mathrm{ml}$ to 72 $\mathrm{mg} / 100 \mathrm{ml}$ in $30 \mathrm{~min}$, only slight transient increases were observed in plasma ACTH. However, in two other diabetic patients a significant rise in $\mathrm{ACTH}$ concentration occurred despite the fact that the lowest plasma glucose concentrations recorded were $70 \mathrm{mg} / 100 \mathrm{ml}$ (A.R., Fig. 13) and $80 \mathrm{mg} / 100 \mathrm{ml}$ (G.O., not shown); the latter patient exhibited typical symptoms and signs of a hypoglycemic reaction at a time when the blood glucose was $80 \mathrm{mg} / 100 \mathrm{ml}$ (preinsulin control level $125 \mathrm{mg} / 100 \mathrm{ml}$ ), after which plasma ACTH rose to an extremely high concentration (700 $\mu \mu \mathrm{g} / \mathrm{ml})$. 
The effectiveness of hypoglycemia in stimulating ACTH was not significantly different at 9:30 a.m. and 4:30 p.m. but hypoglycemia was ineffective in the morning or afternoon after 1 day of suppressive treatment with dexamethasone (Fig. 14). ${ }^{5}$

Histalog administration (Table $V C$ ). One patient (I. C.) given $100 \mathrm{mg}$ Histalog intramuscularly complained of headache and considerable abdominal pain and showed a marked sustained rise in plasma ACTH concentration. Two patients given the same dose subcutaneously without discomfort showed smaller, transient, increases in plasma ACTH within a half hour.

5 In most patients treated for 1 day with dexamethasone, $1 \mathrm{mg}$ every $6 \mathrm{hr}$, a higher fasting blood glucose concentration was observed than on the preceding day and (or) the usual insulin dose of $0.1 \mathrm{U} / \mathrm{kg}$ failed to produce a sufficiently marked hypoglycemia to provide an adequate test of the ACTH response, which was usually completely negative. In two such patients, tests performed $24 \mathrm{hr}$ later, after discontinuation of dexamethasone, showed hypoglycemia and ACTH stimulation equal again to that in the control studies.

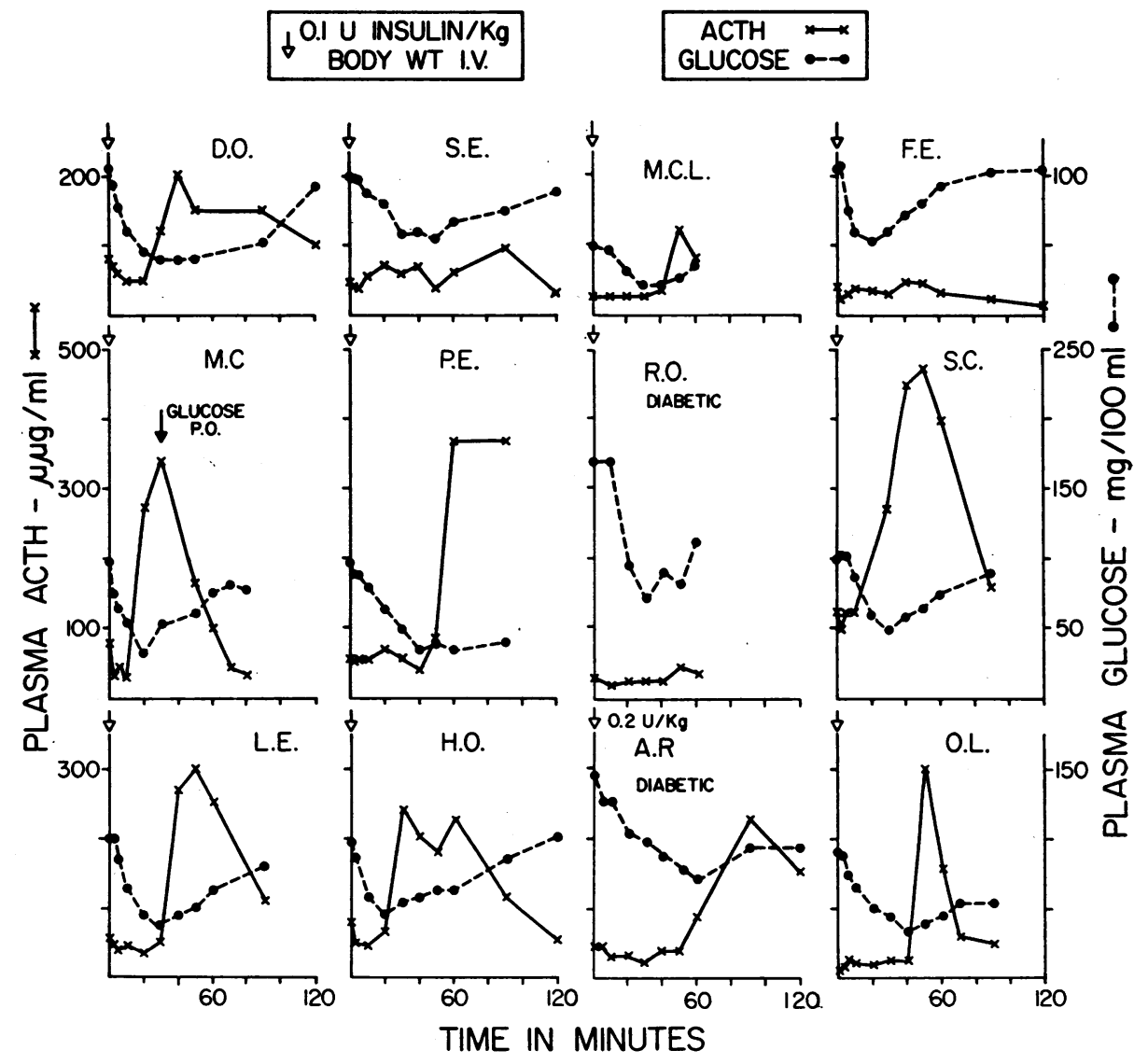

FIgURE 13 Effects of insulin-induced hypoglycemia on plasma ACTH concentrations.

\section{Effect of vasopressin (Table V D)}

After intramuscular injection of $10 \mathrm{U}$ vasopressin, two of three patients exhibited a doubling of the plasma ACTH concentration within 20-30 min.

Plasma ACTH in patients with pituitaryadrenal disease

Hypopituitarism. In plasma samples from eight patients known, on clinical grounds, to be deficient in ACTH production, $\mathrm{B} / \mathrm{F}$ ratios in the same assay were equal to each other within experimental error, and equal or higher than ratios obtained in dexamethasone-suppressed normal subjects. However, in one patient ( $\mathrm{Sm}$.) receiving steroid therapy, who shows good clinical evidence of hypopituitarism and is thought to be steroid-dependent, the $B / F$ ratio determined twice on the same a.m. plasma sample was lower than that observed in other hypopituitary patients and corresponded to a plasma ACTH concentration of $15 \mu \mu \mathrm{g} / \mathrm{ml}$. We 


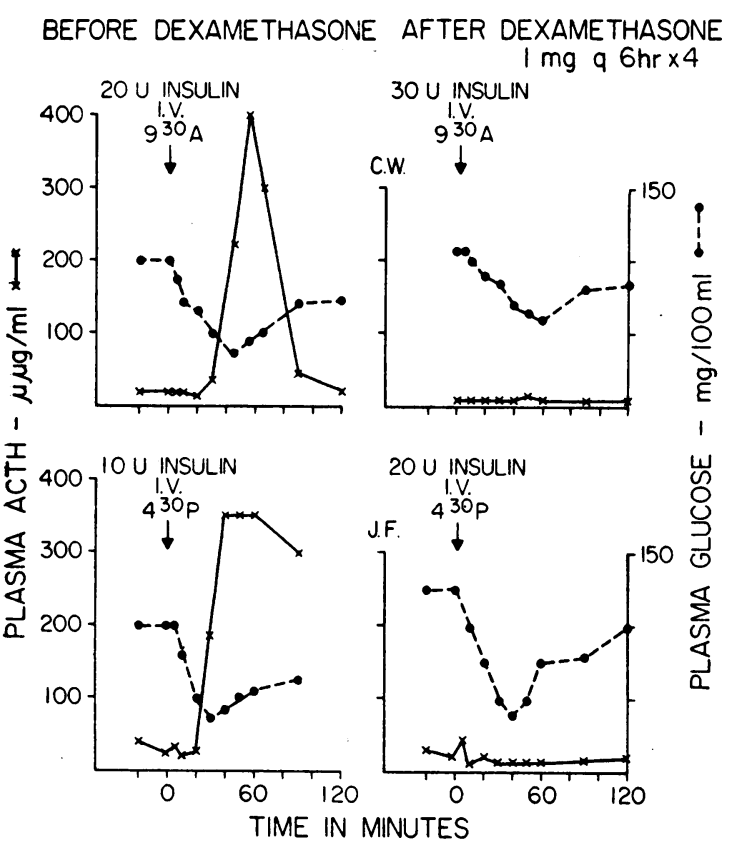

FIGURE 14 Effects of hypoglycemia on plasma ACTH concentrations in morning and afternoon and the influence of prior treatment with dexamethasone, $1 \mathrm{mg}$ every $6 \mathrm{hr}$ for $24 \mathrm{hr}$.

were unable to study $\mathrm{ACTH}$ reserve in this patient.

Hypoadrenalism. In patients with hypoadrenalism due to primary Addison's disease or secondary to bilateral adrenalectomy for severe diabetes mellitus or pheochromocytoma, plasma ACTH concentrations were markedly elevated when steroid therapy was withdrawn (Fig. 9) and normal in one patient receiving maintenance doses of steroids (Fig. 9).

Cushing's disease (Fig. 15). We have had the opportunity to study only a few untreated patients with this disease. In one patient (Car.) plasma ACTH concentrations preoperatively were about $200 \mu \mu \mathrm{g} / \mathrm{ml}$ throughout the day but were considerably higher after bilateral adrenalectomy even though the patient was receiving $50 \mathrm{mg}$ cortisone every $6 \mathrm{hr}$. In another patient (La.) with persistent disease after removal of the right adrenal and $5 \%$ of the left adrenal, both of which were markedly hyperplastic, plasma ACTH level remained about $800 \mu \mu \mathrm{g} / \mathrm{ml}$ throughout the day. In a third patient $\left(\mathrm{D}^{\prime} \mathrm{A}^{\prime}\right)$ with persistent hypercortisolemia after unilateral adrenalectomy, plasma ACTH levels remained above $120 \mu \mu \mathrm{g} / \mathrm{ml}$ throughout most of the day. After removal of the second adrenal, plasma ACTH levels remained above $350 \mu \mu \mathrm{g} / \mathrm{ml}$ even when the patient was on maintenance cortisone ( $37.5 \mathrm{mg} /$ day). In two other cases the patterns were not sufficiently abnormal under the conditions of the studies to conclude that ACTH secretion was not suppressed by high plasma cortisol levels.

After bilateral adrenalectomy plasma ACTH concentrations were very markedly elevated when steroid therapy was withdrawn for $48 \mathrm{hr}$ or longer (Fig. 9). In some cases, the $B / F$ ratios were lower than that corresponding to the last point on the standard curve and assay at a higher dilution of plasma would be needed to provide a precise quantitative determination of ACTH concentration; in cases in which this has been done, values as high as $10 \mathrm{~m} \mu \mathrm{g} / \mathrm{ml}$ have been obtained. Plasma ACTH remained high postadrenalectomy in patients on replacement steroid therapy.

Congenital virilizing adrenogenital syndrome of the 11 $\beta$-hydroxylase deficiency type. One patient with this syndrome had an ACTH level of 400 $\mu \mu \mathrm{g} / \mathrm{ml}$.

Plasma ACTH concentrations in mother and new born at time of delivery. In seven of eight cases, plasma ACTH concentrations were significantly higher in the cord blood (mean $161 \pm 29$ [SD] $\mu \mu \mathrm{g} / \mathrm{ml}$ ) than in maternal venous blood (mean $56 \pm 23$ [sD] $\mu \mu \mathrm{g} / \mathrm{ml}$ ). Concentrations above $60 \mu \mu \mathrm{g} / \mathrm{ml}$ were observed in only two of the mothers but in all of the cord blood specimens.

\section{Turnover of plasma ACTH}

The disappearance of ACTH from plasma after acute stimulation by EST or hypoglycemia cannot be taken as a measure of the turnover of the hormone since the initial decline in concentration after a short-lived peak must be related principally to distribution into extravascular spaces rather than to metabolic turnover alone. However, the fall in concentration to very low levels in such studies and others to be described, does serve to indicate that metabolic products of $\mathrm{ACTH}$ capable of reacting in the immunochemical system do not return in significant quantities to the plasma. $^{6}$

${ }^{6}$ Return to plasma of peptide fragments released by proteolytic degradation of ACTH in tissues would not be detected if such fragments were only poorly immuno- 

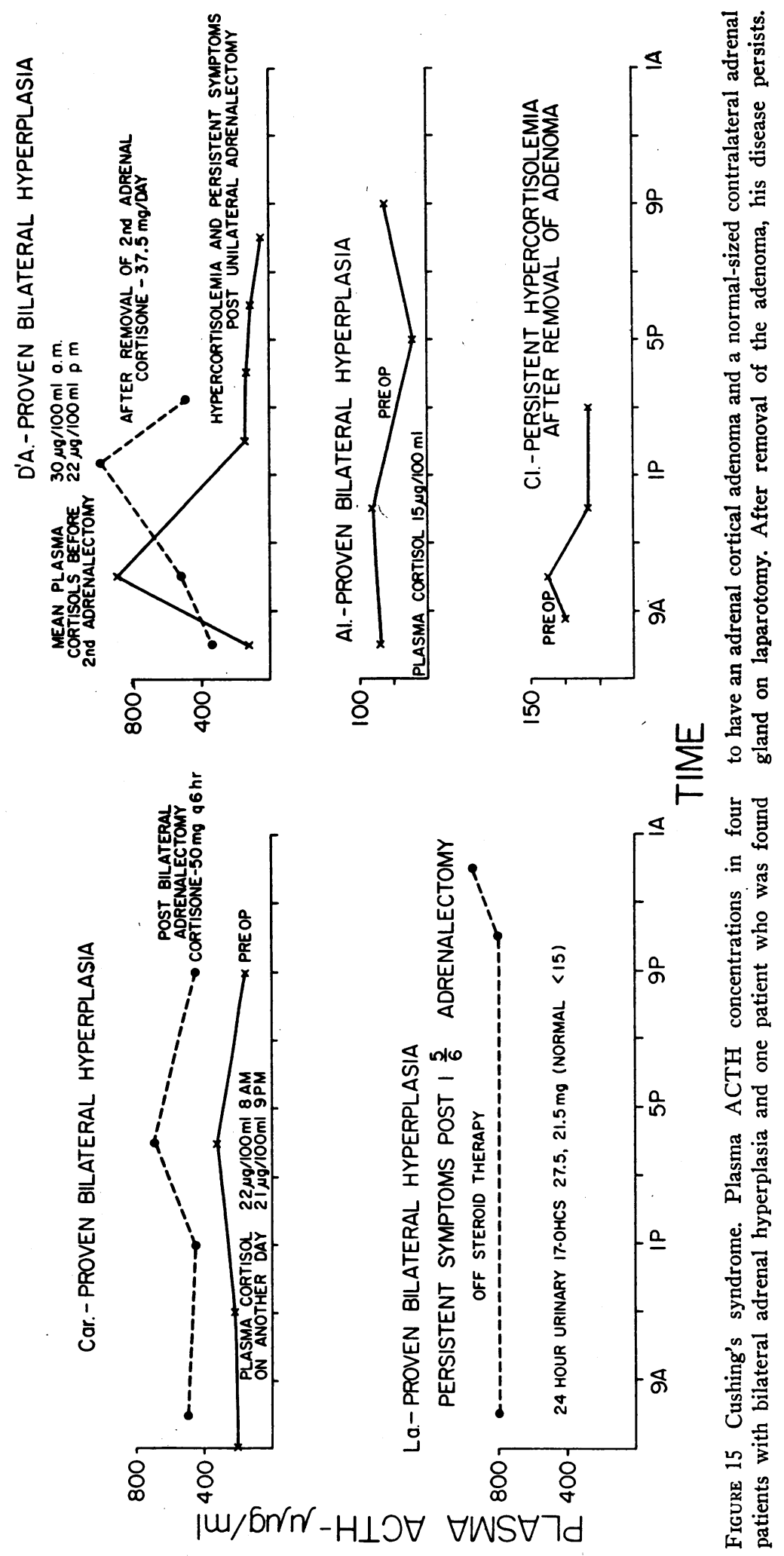


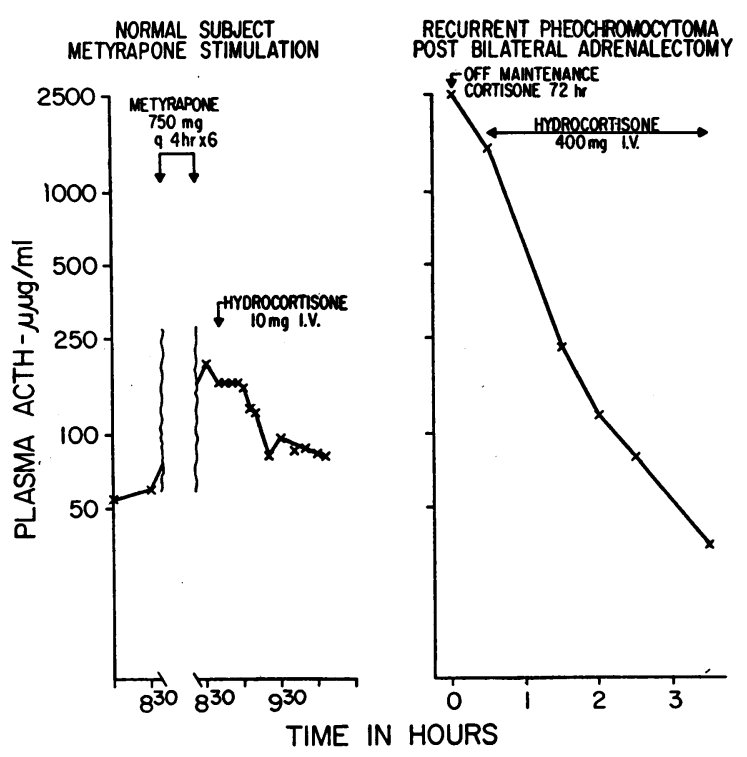

FIGURE 16 Effect of i.v. hydrocortisone on plasma ACTH concentrations. We are indebted to Dr. Josiah Brown, UCLA, for providing the samples from the patient with pheochromocytoma.

In subjects who have maintained elevated plasma ACTH levels for some hours or longer it can be assumed that the hormone has mixed in its volume of distribution. The rate of decline in plasma ACTH after suppression of secretion can then provide some estimate of the upper limits of turnover half-life. Since suppression is not always complete the fractional rate of turnover is likely to be underestimated.

In a bilaterally adrenalectomized subject given $400 \mathrm{mg}$ cortisone by constant intravenous infusion there was observed on one occasion an initial increase in plasma ACTH concentration. On a later repeat study, however, plasma ACTH fell from the outset with an initial half-life of about 22 min (Fig. 16). In the normal subject discussed earlier in whom plasma ACTH had risen to high levels under the influence of metyrapone, a sharp fall in concentration was produced by the oral administration of dexamethasone (patient J. F.). Since samples were not taken at sufficiently frequent intervals it is not possible to determine just when suppression took effect. However, in the period from about $2 \frac{1}{2}$ to $33 / 4 \mathrm{hr}$ after institution of dexamethasone treatment the plasma ACTH con-

reactive and can therefore not be excluded as a possibility, particularly in the case of the hormonally inactive C terminal fragments. centration fell from 125 to $19 \mu \mu \mathrm{g} / \mathrm{ml}$ in $80 \mathrm{~min}$ indicating a half-life of not more than $30 \mathrm{~min}$. In a similar experiment in a patient given $10 \mathrm{mg}$ hydrocortisone intravenously, plasma ACTH fell from 165 to $82 \mu \mu \mathrm{g} / \mathrm{ml}$ between $8: 58$ and $9: 20$ a.m., indicating a half-life of not more than $22 \mathrm{~min}$ (Fig. 16).

\section{DISCUSSION}

The improvement in sensitivity of the radioimmunoassay for plasma ACTH described here has been made possible principally by selection of a sensitive antiserum and by the use of conditions that permit reduction of the "tracer" concentration of labeled ACTH to about $1 \mu \mu \mathrm{g} / \mathrm{ml}$. The latter measure would not alone suffice with other antisera that yield significantly less sharp slopes in the standard curve. In several experiments we have observed that a still greater sensitivity is obtainable with this antiserum by using a "tracer" concentration of $0.5 \mu \mu \mathrm{g} / \mathrm{ml}$. This can be effected either by reducing the amount of "tracer" in the same volume or by doubling the volume of incubation mixture. However, the present sensitivity of $1 \mu \mu \mathrm{g} / \mathrm{ml}$ is adequate for all practical purposes and the needs do not justify the further inconvenience of prolongation of counting time or the use of larger volumes. Under present conditions it is possible to set up a 700 tube assay without difficulty. Once the plasma samples are pipetted, the labeled hormone, antiserum, and diluent are added to 350 tubes $/ \mathrm{hr}$. With the talc tablets, bound and free hormone are separated at the rate of more than 150 tubes/hr.

Since a biologic unitage cannot be applied to immunochemical reactivity, all plasma ACTH concentrations have been given in $\mu \mu \mathrm{g} / \mathrm{ml}$. However, for the purpose of comparison with the results of bioassay it is useful to make the conversion from $\mu \mu \mathrm{g} / \mathrm{ml}$ to $\mathrm{mU} / 100 \mathrm{ml}$, in which units the results by bioassay have always been presented. The $\mathrm{Li}$ human ACTH and the Lerner-Upton human ACTH 8B did not differ significantly in immunochemical potency and we may take the biologic potency of the standards used as $140 \mathrm{U} / \mathrm{mg}$. A plasma concentration of $20 \mu \mu \mathrm{g} / \mathrm{ml}$ is therefore equivalent in immunochemical potency to that of a standard with a biologic potency of $0.28 \mathrm{mU} /$ $100 \mathrm{ml}$. There is a paucity of bioassay data on normal concentrations in human subjects because 
of the lack of sufficient sensitivity of the bioassays to measure the low plasma concentrations. On the basis of inability to detect hormone in oxycellulose extracts of $40 \mathrm{ml}$ blood by the adrenal ascorbic acid depletion test, Sayers (23) concluded that normal human plasma contains less than $0.5 \mathrm{mU} /$ $100 \mathrm{ml}$ whole blood. Since then, other workers extracting larger volumes $(200-1000 \mathrm{ml})$ were able to detect the presence of hormone by this method and estimated its concentration in human plasma to be about $0.7 \mathrm{mU} / 100 \mathrm{ml}$ whole blood (24) and $1 \mathrm{mU} / 100 \mathrm{ml}$ whole blood (25). Unless ACTH is present in blood cells, the values in plasma would be almost twice as great. The greater sensitivity of the Lipscomb-Nelson method $(26,27)$, which measures the increase in corticosterone secretion into the adrenal vein of the hypophysectomized rat, enabled Vance, Reddy, Nelson, and Thorn (28) to measure the hormone in $10 \mathrm{ml}$ plasma after concentration by lyophilization to dryness and redissolution in $5 \mathrm{ml} 0.01 \mathrm{~N}$ $\mathrm{HCl}$; at 8-9 a.m., the concentrations were found to be in the range $0.4-1.0 \mathrm{mU} / 100 \mathrm{ml}$ plasma. Smaller volumes of plasma $(3-5 \mathrm{ml})$ do not generally reveal hormone by this method (28-30). However, by extraction and concentration from $250 \mathrm{ml}$ plasma, Ney, Shimizu, Nicholson, Island, and Liddle (31) estimated concentrations at 6 a.m. and 6 p.m. to average $0.25 \mathrm{mU} / 100 \mathrm{ml}$ plasma and $0.11 \mathrm{mU} / 100 \mathrm{ml}$ plasma, respectively. These estimates assumed that the hormone was completely extracted from the large volumes of normal plasma on the basis of earlier (30) recovery experiments on smaller volumes of plasma containing high hormone concentrations. In a previous study on radioimmunoassay of extracted normal plasma (correcting for incomplete recovery), we found a.m. concentrations to average about $0.6 \mathrm{mU} / 100 \mathrm{ml}$ plasma (range 0.34-0.88) in nine normal subjects (1). By the same extraction procedure and radioimmunoassay method, Demura, West, Nugent, Nakagawa, and Tyler (32) found a mean value of $0.5 \mathrm{mU} / 100 \mathrm{ml}$ (range $0.3-0.7 \mathrm{mU} / 100$ $\mathrm{ml}$ ) in 10 normal subjects at 8 a.m.

In the present larger series, the concentrations determined by radioimmunoassay in normal subjects (equivalent to $0.31 \mathrm{mU} / 100 \mathrm{ml}$ plasma in a.m. and $0.13 \mathrm{mU} / 100 \mathrm{ml}$ plasma in p.m.) correspond closely to the lowest values reported by bioassay. However, from the results of the present study it would appear that the range of normal concentrations may be quite great. The very rapid disappearance of hormone from the circulation in the stimulation experiments with insulin and EST and the equally rapid spontaneous decreases frequently observed in control and hospital patients indicate that peak concentrations of plasma ACTH may be very short-lived. Samples taken a half hour or an hour apart from the same individual may show very great differences in concentration. The disagreements in values obtained from small numbers of subjects by different investigators may therefore be more apparent than real. However, the values obtained by Ney et al. (31) at 6 a.m. average significantly lower than those obtained even later in the morning by other investigators using the same assay system (28); it is possible that the extraction of the large volumes of plasma by Ney et al. (31) was not as efficient as that observed with smaller volumes (30).

From the diurnal variations earlier observed by us in four cases (22) and Demura et al. in two cases (32) and from the additional observations reported here, it would appear that an early morning peak may frequently be missed in samples taken at 8 a.m. or later, especially in persons accustomed to early rising. Control subject C. Iv., who showed an essentially flat curve from 6 a.m. to 11 p.m., usually leaves for work about $5: 30$ a.m. and could be expected to have his peak ACTH concentration several hours earlier. In hospital patients, however, high levels were frequently obtained at 6 a.m. although concentrations usually fell off later in the day.

Perhaps the essential point to be made regarding these plasma ACTH concentrations is the lack of information that can be derived from isolated observations, except that the demonstration of a high level excludes the existence of ACTH deficiency and a near zero value in association with hypocortisolemia provides evidence of pituitary insufficiency. Transient spurts in ACTH secretion, the rapid turnover of plasma ACTH, anomalous deviations from the "typical" circadian rhythm in normal subjects and the characteristic response of ACTH secretion to the acute disturbances in physiologic equilibrium that are classified as "stressful" stimuli all contribute to fluctuations in plasma ACTH and complicate what might otherwise be a simple feedback regulation of ACTH 
secretion by steroid levels in one or more controller sites. It has elsewhere been emphasized (22) that, unlike the serum levels of calcium, uric acid, thyroxine, glucose, etc., concentrations of several of the peptide hormones vary rather widely among normal subjects and tend to undergo marked fluctuations during the day in individual subjects. These characteristics apply to plasma ACTH, which even when closely paralleling the plasma cortisol concentration, shows a much greater spread between high and low points. So, too, the 10-20-fold rises in ACTH concentration after hypoglycemia or other stimulation are far more impressive than are usually seen in the plasma cortisol level in the general circulation. Even were the adrenal cortex to respond proportionately to the logarithm of the plasma ACTH concentration, the longer half-life of plasma cortisol would tend to blunt the changes in steroid concentration but, in addition, there is reported to be a diurnal variation in the responsiveness of the cortex to ACTH (33). The present study indicates also that there are significant variations in plasma ACTH levels among normal individuals.

In view of the sporadic fluctuations in plasma $\mathrm{ACTH}$, a full appreciation of the dynamics of ACTH secretion requires multiple determinations at frequent intervals and an evaluation of the responses to stimuli and suppressants.

The results of the metyrapone experiments indicate that a single dose at 9 a.m. was not as effective as repeated doses during the morning in stimulating ACTH release. However, even when an effective level of metyrapone was maintained by repeated doses, plasma ACTH declined towards the evening in most cases. Also, the later in the day that metyrapone was started, the more difficult it was to elicit an increase in plasma ACTH over the next few hours. Similar conclusions were reached by Martin and Hellman (34) who found a smaller increment in urinary 17 OHCS excretion in response to i.v. metyrapone in the late afternoon and evening than in the early morning, a difference that could not be explained by the decreased responsiveness of the adrenal cortex to ACTH late in the day. These results are consistent with the suggestion of Liddle (35) that this agent increases ACTH secretion principally through its inhibitory action on the $11 \beta$-hydroxylase activity and therefore on corti- sol synthesis in the adrenal cortex. Others have suggested that another action may be necessary to explain its effect $(28,36)$. Indeed, Vance et al. (28) were unable to demonstrate a rise in plasma ACTH in normal subjects given metryapone intravenously or by mouth or in Addisonian patients given it intravenously; only slight increases were observed by Liddle, Island, and Meador (30) within $24 \mathrm{hr}$ when metyrapone was given orally, although by $72 \mathrm{hr}$ plasma ACTH concentrations had risen to $1-2 \mathrm{mU} / 100 \mathrm{ml}$ in all of the six subjects reported. In the present study of a much larger number of patients, concentrations had reached $100-500 \mu \mu \mathrm{g} / \mathrm{ml}$ (equivalent to $1.4-7.0$ $\mathrm{mU} / 100 \mathrm{ml}$ ) by the morning after institution of therapy in every case even when metyrapone had been started late in the preceding afternoon. The inability of metyrapone to provoke a release of $\mathrm{ACTH}$ in the evening of the 1 st day is not surprising if its action is solely through its inhibition of cortisol synthesis, since the normally low plasma cortisol concentrations at that time are likewise ineffective. The diurnal rhythm of plasma ACTH and plasma cortisol are a consequence of the insensitivity of the hypothalamico-hypophyseal system to feedback stimulation at night although the pituitary-adrenal system may be even more sensitive to stimulation by vasopressin (37) and pyrogen (38) at this time. The ability of dexamethasone (patient J. R.) and hydrocortisone (Fig. 16) to bring about an abrupt and sustained decline in plasma ACTH concentration in patients maintained on metyrapone further supports the conclusion of Liddle (35) regarding the mechanism of action of this agent.

The results obtained on the stimulation of ACTH secretion by hypoglycemia, electric shock, Histalog, surgical procedures and vasopressin and the inhibitory effect of dexamethasone on hypoglycemia-induced secretion do not require extensive discussion since they are simply confirmatory of earlier work in animals and man in which bioassay of ACTH or plasma steroid determinations had been performed. In particular, the classic studies of Sayers and Sayers (39) established that application of a variety of stressful stimuli was followed by the appearance in blood of adrenal ascorbic acid-depleting activity which behaved like pituitary adrenocorticotropin and that administration of cortisol and other steroids could block 
the response. The ability of vasopressin to provoke ACTH secretion (40) was also first demonstrated by bioassay of plasma ACTH.

Likewise, high plasma ACTH concentrations in Addison's disease have been repeatedly confirmed by bioassay methods $(23,39,41,42)$ and by radioimmunoassay as well $(1,32)$, after the initial report of Taylor, Albert, and Sprague (43). Extraordinarily high levels were found by Nelson, Meakin, and Thorn (44) in patients subjected to bilateral adrenalectomy for Cushing's syndrome associated with bilateral adrenal hyperplasia. Elevation of blood ACTH levels was also reported in children with congenital adrenal hyperplasia (45) after the prediction of Bartter, Albright, Forbes, Leaf, Dempsey, and Carroll (46) that this would be the case and this finding was confirmed by Demura et al. (32) using radioimmunoassay.

Results on plasma ACTH concentrations in untreated Cushing's syndrome associated with bilateral adrenal hyperplasia have not been consistent. Davies (24) measured plasma ACTH by the adrenal ascorbic acid depletion assay and reported concentrations of $2.16 \mathrm{mU} / 100 \mathrm{ml}$ and $1.80 \mathrm{mU} / 100 \mathrm{ml}$ respectively in two cases compared to $0.7 \mathrm{mU} / 100 \mathrm{ml}$ in two large pools $(500$ $1000 \mathrm{ml}$ ) of normal whole blood extracted by oxycellulose. Using the Lipscomb-Nelson assay (26, 27), Miyake, Imura, and Muranaka (29) did not detect plasma hormone in one case and Vance et al. (28) found normal values in six patients; a seventh patient in the latter study had high values but had previously undergone bilateral adrenalectomy. With the same assay system but using extracts of plasma hormone, Ney et al. (31) found the 6 a.m. concentrations in nine patients with untreated Cushing's disease to average 2.5 times the normal concentration although only in two patients were the concentrations distinctly above normal; these authors suggested that since these patients usually lacked diurnal variation in plasma 17-OHCS concentration (47), they probably also lack diurnal variation in ACTH secretion. The present study bears out this suggestion. Although hypercortisolemic patients with Cushing's disease did not always have a.m. levels of plasma ACTH distinctly elevated above those occasionally encountered in other hospital patients, concentrations usually remained elevated throughout the day.
Finally, some "order of magnitude" estimate of $\mathrm{ACTH}$ turnover may be derived on the basis of the data presented. Accepting an average plasma concentration of $22 \mu \mu \mathrm{g} / \mathrm{ml}$ at 8-10 a.m. and 10 $\mu \mu \mathrm{g} / \mathrm{ml}$ at $10 \mathrm{p} . \mathrm{m}$. and short-lived spikes in concentration at 4-6 a.m., a crude estimate for the integrated mean normal concentration throughout the day would appear to be about $18 \mu \mu \mathrm{g} / \mathrm{ml}$. If the space of ACTH distribution corresponds to extracellular space (or 14 liters in a $70 \mathrm{~kg}$ man) and the mean turnover $t_{1}$ is $25 \mathrm{~min}$, the turnover in normal subjects is calculated to be $7.24 \mu \mathrm{g}$ or $1 \mathrm{U} /$ day. Since the turnover $t_{\frac{1}{2}}$ for endogenous ACTH is probably less than $25 \mathrm{~min}$, as has previously been observed in one case (1), the actual turnover is probably somewhat higher. The results are not incompatible with the observations of Liddle et al. (30) who found that slight elevations of plasma and urinary steroids were produced by a constant intravenous infusion of $\mathrm{ACTH}$ at the rate of $1.2 \mathrm{U} /$ day.

\section{ACKNOWLEDGMENTS}

We are indebted to Doctors Choh Hao Li, Aaron Lerner, and Virginia Upton for supplies of human ACTH used in these studies; to Doctors Dorothy Krieger, Richard Doe, Josiah Brown, Maria New, Leonard Kleinman, W. J. Blankenship, and numerous other physicians who provided samples for our studies; to Doctors Nora Varsano and Elsa Echemendia of our laboratory for aid in obtaining samples in some of the special studies reported; to Charles Iversen, Walter Ormond, and Manuel Villazon for technical assistance and to Violet Mallory, Frieda Steiner, and Carol Montemurro for secretarial assistance; to Gloria Spevacek, Elizabeth Walsin, Glen Harahan, and Bernard Harris of the Medical Illustration Department for the preparation of the figures.

\section{REFERENCES}

1. Yalow, R. S., S. M. Glick, J. Roth, and S. A. Berson. 1964. Radioimmunoassay of human plasma ACTH. J. Clin. Endocrinol. Metab. 24: 1219.

2. Berson, S. A., R. S. Yalow, A. Bauman, M. A. Rothschild, and K. Newerly. 1956. Insulin-I ${ }^{181}$ metabolism in human subjects: demonstration of insulin binding globulin in the circulation of insulin-treated subjects. J. Clin. Invest. $35: 170$.

3. Berson, S. A., and R. S. Yalos. 1958. Isotopic tracers in the study of diabetes. In Advances in Biological and Medical Physics. Academic Press Inc., New York. 6: 349.

4. Yalow, R. S., and S. A. Berson. 1959. Assay of plasma insulin in human subjects by immunological methods. Nature. (London). 184: 1648.

Radioimmunoassay of ACTH in Plasma 2749 
5. Yalow, R. S., and S. A. Berson. 1966. Labeling of proteins-problems and practices. Trans. N. Y. Acad. Sci. 28: 1033.

6. Berson, S. A., and R. S. Yallow. 1966. Iodoinsulin used to determine specific activity of Iodine-131. Science. 152: 205.

7. Hunter, W. M., and F. C. Greenwood. 1962. Preparation of Iodine-131 labeled human growth hormone high specific activity. Nature. (London). 194: 495.

8. Yalow, R. S., and S. A. Berson. 1966. Purification of 181-I-parathyroid hormone with microfine granules of precipitated silica. Nature. (London). 212: 357.

9. Rosselin, G., R. Assan, R. S. Yalow, and S. A. Berson. 1966. Separation of antibody-bound and unbound peptide hormones labeled with iodine- 131 by talcum powder and precipitated silica. Nature. (London). 212: 355.

10. Ferrebee, J. W., B. B. Johnson, J. C. Mithoefer, and J. W. Gardella. 1951. Insulin and adrenocorticotropin labeled with radio-iodine. Endocrinology. 48: 277.

11. Yalow, R. S., and S. A. Berson. 1960. Immunoassay of endogenous plasma insulin in man. J. Clin. Invest. 39: 1157

12. Richards, J. B., and G. Sayers. 1951. Fate and excretion of adrenocorticotrophic hormone. Proc. Soc. Exptl. Biol. Med. 77: 87.

13. Dedman, M. L., T. H. Farmer, and C. J. O. R. Morris. 1955. Oxidation-reduction properties of adrenocorticotrophic hormone. Biochem. J. 59: xii.

14. Dedman, M. L., T. H. Farmer, and C. J. O. R. Morris. 1961. Studies on pituitary adrenocorticotrophin. Biochem. J. 78: 348.

15. Mirsky, I. A., G. Perisutti, and N. C. Davis. 1959. The destruction of glucagon, adrenocorticotropin and somatropin by human blood plasma. J. Clin. Invest. 38: 14.

16. Yalow, R. S., and S. A. Berson. 1968. Topics on radioimmunoassay of peptide hormones. I. Labeling of hormones. II. Separation of free labeled hormone bound to antibodies. International Symposium on Protein and Polypeptide Hormones, 19-25 May 1968, Liege, Belgium. Excerpta Medica Foundation. 36-44.

17. Sweat, M. L. 1954. Sulfuric acid-induced fluorescence of corticosteroids. Anal. Chem. 26: 773.

18. Nelson, N. 1944. A photometric adaptation of the Somogyi method for determination of glucose. J. Biol. Chem. 153: 375.

19. Berson, S. A., and R. S. Yalow. 1959. Quantitative aspects of reaction between insulin and insulin-binding antibody. J. Clin. Invest. 38: 1996.

20. Berson, S. A., R. S. Yalow, S. M. Glick, and J. Roth. 1964. Immunoassay of protein and peptide hormones. Metab. Clin. Exptl. 13: 1135.

21. Berson, S. A., and R. S. Yalow. Recent advances in immunoassay of peptide hormones in plasma. In Proceedings of International Diabetes Federation 6th Congress, Stockholm, Sweden, July 30-August 4, 1967. Excerpta Medication Foundation. In press.

22. Berson, S. A., and R. S. Yalow. Peptide hormones in plasma. The Harvey Society, N. Y. Academy of
Medicine, Dec. 15, 1966. In The Harvey Lectures, The Maple Press Co., Inc., York. 107.

23. Sayers, G. 1955. Editorial. Blood ACTH. J. Clin. Endocrinol. Metab. 15: 754.

24. Davies, B. M. A. 1960. Blood corticotrophin in Cushing's syndrome. Nature. (London). 188: 1203.

25. Fujita, T. 1957. Determination of corticotropin (ACTH) in human blood and urine by a modified oxycellulose method. J. Clin. Endocrinol. Metab. 17: 512.

26. Lipscomb, H., and D. H. Nelson. 1959. Measurement of corticosterone in rat adrenal venous plasma as a bioassay for ACTH. Federation Proc. 18: 95. (Abstr. 373)

27. Lipscomb, H. S., and D. H. Nelson. 1960. Dynamic changes in ascorbic acid and corticosteroids in adrenal vein blood after ACTH. Endocrinology. 66: 144.

28. Vance, V. K., W. J. Reddy, D. H. Nelson, and G. W. Thorn. 1962. Adrenocorticotropic hormone in human plasma. J. Clin. Invest. $41: 20$.

29. Miyake, T., H. Imura, and H. Muranaka. 1962. Plasma adrenocorticotropic hormone in normal subjects and patients with endocrine disorders; with observations on the effect of adrenal steroids and adrenal $11 \beta$-hydroxylase inhibitors. Endocrinol. Japan. 9: 223.

30. Liddle, G. W., D. Island, and C. K. Meador. 1962. Normal and abnormal regulation of corticotropin secretion in man. Recent Progr. Hormone Res. 18: 125.

31. Ney, R. L., N. Shimizu, W. E. Nicholson, D. P. Island, and G. W. Liddle. 1963. Correlation of plasma ACTH concentration with adrenocortical response in normal human subjects, surgical patients, and patients with Cushing's disease. J. Clin. Invest. 42: 1669.

32. Demura, H., C. D. West, C. A. Nugent, K. Nakagawa, and F. H. Tyler. 1966. A sensitive radioimmunoassay for plasma ACTH levels. J. Clin. Endocrinol. Metab. 26: 1297.

33. Perkoff, G. T., K. Eik-Nes, C. A. Nugent, H. L. Fred, R. A. Nimer, L. Rush, L. T. Samuels, and F. H. Tyler. 1959. Studies of the diurnal variation of plasma 17-hydroxycorticosteroids in man. J. Clin. Endocrinol. Metab. 19: 432.

34. Martin, M. M., and D. E. Hellman. 1964. Temporal variation in SU-4885 responsiveness in man: evidence in support of circadian variation in ACTH secretion. J. Clin. Endocrinol. Metab. 24: 253.

35. Liddle, G. W. 1960 . Tests of pituitary-adrenal suppressibility in the diagnosis of Cushing's syndrome. J. Clin. Endocrinol. Metab. 20: 1539.

36. Vernikos-Danellis, J. 1965. The regulation of the synthesis and release of ACTH. Vitamins Hormones. 23: 97.

37. Clayton, G. W., L. Librik, R. L. Gardner, and R. Guillemin. 1963. Studies on the circadian rhythm of pituitary adrenocorticotropic release in man. J. Clin. Endocrinol. Metab. 23: 975.

38. Takebe, K., C. Setaishi, M. Hirama, M. Yamamoto, and Y. Horivchi. 1966. Effects of a bacterial pyrogen 
on the pituitary-adrenal axis at various times in the 24 hours. J. Clin. Endocrinol. Metab. 26: 437.

39. Sayers, G., and M. A. Sayers. 1947. Regulation of pituitary adrenocorticotrophic activity during response of rat to acute stress. Endocrinology. 40: 265.

40. Nagareda, C. S., and R. Gaunt. 1951. Functional relationship between the adrenal cortex and posterior pituitary. Endocrinology. 48: 560.

41. Parrott, D. M. V. 1955. Assay of adrenocorticotrophic activity in plasma extracts. J. Endocrinol. 12: 120.

42. Bethune, J. E., D. H. Nelson, and G. W. Thorn. 1957. Plasma adrenocorticotrophic hormone in Addison's disease and its modification by the administration of adrenal steroids. J. Clin. Invest. 36: 1701.

43. Taylor, A. B., A. Albert, and R. G. Sprague. 1949. Adrenotrophic activity of human blood. Endocrinology. $45: 335$.

44. Nelson, D. H., J. W. Meakin, and G. W. Thorn. 1960. ACTH-producing pituitary tumors following adrenal- ectomy for Cushing's syndrome. Ann. Intern. Med. 52: 560 .

45. Sydnor, K. L., V. C. Kelly, R. B. Raile, R. S. Ely, and G. Sayers. 1953. Blood adrenocorticotrophin in children with congenital adrenal hyperplasia. Proc. Soc. Exptl. Biol. Med. 82: 695.

46. Bartter, F. C., F. Albright, A. P. Forbes, A. Leaf, E. Dempsey, and E. Carroll. 1951. The effects of adrenocorticotropic hormone and cortisone in the adrenogenital syndrome associated with congenital adrenal hyperplasia: an attempt to explain and correct its disordered hormonal pattern. J. Clin. Invest. 30: 237.

47. Doe, R. P., J. A. Vennes, and E. B. Flink. 1960. Diurnal variation of 17-hydroxycorticosteroids, sodium, potassium, magnesium and creatinine in normal subjects and in cases of treated adrenal insufficiency and Cushing's syndrome. J. Clin. Endocrinol. Metab. 20: 253 . 